\title{
Türkiye ile Avrupa Birliği Arasında Doğu Akdeniz Meselesine İlişkin Güncel Siyasi Gelişmeler ve Meselenin Uluslararası Hukuk Boyutu
}

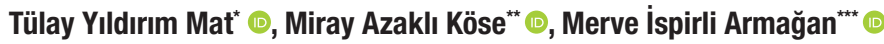

Öz

Doğu Akdeniz meselesi son dönemde Türkiye'nin uluslararası ilişkilerindeki en önemli sorunlardan biri haline gelmiştir. Doğu Akdeniz'de Türkiye ve Kuzey Kıbrıs Türk Cumhuriyeti'ne karşı Yunanistan ve Güney Kıbrıs Rum Yönetimi bloğu arasında yaşanan gelişmeler, bölgede kıyısı bulunan diğer devletlerle birlikte Avrupa Birliği ülkeleri için de oldukça önemli bir hâle gelmiştir. Bu makalede Doğu Akdeniz meselesinin hukuki ve siyasi temel sebeplerine değinilmiş ve meseleye ilişkin Türkiye ile Avrupa Birliği arasındaki güncel siyasi gelişmeler irdelenmiştir. Deniz yetki alanlarının esas olarak devletler arasında akdedilecek anlaşmalar ile belirlenmesi prensibi, Doğu Akdeniz'e kıyısı olan devletleri bir antlaşma akdetme yarışına sokmuştur. Ancak bu antlaşmalar neticesinde ortaya çıkan tablo, Doğu Akdeniz'de birbiri ile çakışan deniz yetki alanlarının oluştuğunu göstermektedir. Türkiye, Güney Kıbrıs Rum Yönetimi'nin Kıbrıs Cumhuriyeti sıfatıyla diğer devletlerle yaptığı anlaşmaları hükümsüz kabul ettiğini ifade etmektedir. Türkiye'nin 2019'da Libya ile akdetmiş olduğu deniz yetki alanlarının sınırlandırımasına ilişkin antlaşma ile belirlenen sınır ise Yunanistan'ın iddia ettiği münhasır ekonomik bölgede yer almaktadır. Diğer yandan Doğu Akdeniz konusunda Yunanistan'dan taraf olan Avrupa Birliği, Türkiye’ye karşı sert yaptırımların uygulanmasını dile getirmektedir. Avrupa Birliği'nin bu tavrı müzakerelerin yürütülmesini ve elde edilecek sonucun içeriğini etkileyebilecek niteliktedir. Belirtmek gerekir ki, hem Güney Kıbrıs Rum Yönetimi hem de Yunanistan'ın tarafı olduğu bu uyuşmazlıkta problemin özünü deniz yetki alanlarının sınırlandırılmasında adalara nasıl bir etki tanınacağı sorusu oluşturmaktadır. Bu noktada adaların da deniz yetki alanlarının sınırlandırılmasında hakça ilkelere tâbi olduğu açıktır. Bu nedenle makalenin son kısmında söz konusu somut uyuşmazlık özelinde hangi ilkelerin gündeme gelebileceği incelenmiştir.

\section{Anahtar Kelimeler \\ Doğu Akdeniz, Avrupa Birliği, Kıbrıs, Deniz Yetki Alanlarının Sınırlandırılması, Münhasır Ekonomik Bölge, Kıta Sahanlığı}

Current Political Developments Between Turkey and the European Union in the Eastern Mediterranean Conflict and Its International Law Aspect

\begin{abstract}
The Eastern Mediterranean conflict has recently become one of the major issues regarding international relations of Turkey. Developments between Turkey-the Northern Republic of Cyprus bloc and Greece-the Greek Administration of Southern Cyprus (TGASC) bloc, have become a significant subject both for the coastal states of the Eastern Mediterranean region and the member states of the European Union (EU). Focusing on the use of international agreements as the primary means of delimitating the maritime zones has brought about a fevered rush among Eastern Mediterranean coastal states seeking to conclude agreements as quickly as possible. The evidence after the conclusion of the agreements indicates that there may well be overlapping maritime zones in the region. Turkey has announced that the agreements concluded
\end{abstract}

* Sorumlu Yazar: Tülay Yıldırım Mat (Doç.Dr.), İstanbul Medeniyet Üniversitesi, Hukuk Fakültesi, Milletlerarası Hukuk Anabilim Dalı, İstanbul, Türkiye. E-posta: tulay.yildirim@medeniyet.edu.tr ORCID: 0000-0002-3035-9693

** Miray Azaklı Köse (Dr.), İstanbul Medeniyet Üniversitesi, Hukuk Fakültesi, Milletlerarası Hukuk Anabilim Dalı, İstanbul, Türkiye. E-posta miray.kose@medeniyet.edu.tr ORCID: 0000-0002-9723-8618

*** Merve İspirli Armağan (Arş. Gör.), İstanbul Medeniyet Üniversitesi, Hukuk Fakültesi, Uluslar Arası Hukuk Anabilim Dalı, İstanbul, Türkiye. E-posta: merve.ispirli@medeniyet.edu.tr ORCID: 0000-0002-4928-5321

Attf: Yildirim Mat T, Azakli Kose M, Ispirli Armagan M, "Türkiye ile Avrupa Birliği Arasında Doğu Akdeniz Meselesine i̇lişkin Güncel Siyasi Gelişmeler ve Meselenin Uluslararası Hukuk Boyutu” (2021) 79(3) İstanbul Hukuk Mecmuası 1067. https://doi.org/10.26650/mecmua.2021.79.3.5211 
between TGASC under the name of the Republic of Cyprus and certain other states have been deemed invalid by Turkey. This article will analyze the primary legal and political reasons for this Eastern Mediterranean conflict as well as current political developments between Turkey and the EU on the subject.

Moreover, the boundaries determined by the agreement on the delimitation of the maritime zones between Turkey and Libya concluded in 2019 are located in the exclusive economic zone claimed by Greece. The EU has announced strict economic and political sanctions against Turkey, siding with Greece. This EU attitude may affect the negotiations and outcome. Given that TGASC and Greece are parties to the dispute, the core of the problem is to what extent islands will affect the delimitation of the maritime zones. At this point, equitable principles should and are applicable also to the islands. Finally, the ultimate principles that will apply to the dispute in question are discussed in the final section of the article.

\section{Keywords}

Eastern Mediterranean, The European Union, Cyprus, The Delimitation of The Maritime Zones, Exclusive Economic Zone, Continental Shelf

\section{Extended Summary}

Disputes regarding the delimitation of maritime zones in the Eastern Mediterranean have a long history because they do not refer to a purely legal problem. First, the status of the Greek Administration of Southern Cyprus and its presentation and acceptance as the sole representative of the island in the international domain has been subject to objections from Turkey for many years. Because the Turkish Republic of Northern Cyprus and its maritime borders have not been respected and recognized by, such as Greece and the European Union, a purely legal solution to the problem has not been easily discernible. Therefore, the delimitation of maritime zones between Turkey and Cyprus has continued to be a multifaced problem with both political and legal dimensions. Furthermore, as of 2003, while the Greek Administration of Southern Cyprus rapidly began to conclude bilateral agreements on the delimitation of maritime zones with certain coastal Mediterranean states, Turkey had concluded an agreement with the Turkish Republic of Northern Cyprus in 2011 and an agreement with Libya in 2019. In the meantime, both the Turkish Republic of Northern Cyprus and the Greek Administration of Southern Cyprus granted exploration and exploitation licenses to certain companies. Drilling activities by Turkey's TPAO's based on these licenses in Northern Cyprus have drawn adverse reactions from Greece and the European Union particularly and raised the tension between these various parties.

According to international law, the delimitation of the exclusive economic zone and continental shelf is solely a matter between the coastal states. However, the European Union has nonetheless become a party to the dispute. Because Greece and Southern Cyprus have become members of the European Union from in 1981 and 2004, respectively, the Aegean Sea and Cyprus have become a part of the borders of the Union. The candidate status of Turkey for the membership in the Union has been recognized from 1999. Because candidate states must comply with the principle of the peaceful settlement of border disputes or give consent to the jurisdiction of the 
International Court of Justice (ICJ) for the same, the European Union has taken part in this ongoing Eastern Mediterranean conflict. Therefore, following the analysis of the reasons for the conflict between Turkey, Greece, and Southern Cyprus, the effects of that dispute on the relationship between Turkey and the European Union will be briefly discussed in this article.

It is well-known that Turkey and Greece have a long-standing history of problems regarding the delimitation of maritime zones in the Aegean Sea and the Eastern Mediterranean. The three primary elements of the Turkish-Greek maritime disputes can be summarized as follows: 1) Disagreement on the breadth of Greek territorial waters and the ownership of certain islands or isles in the Aegean Sea; 2) the extent of the two states' exclusive economic zones and continental shelves in the eastern Mediterranean; and 3) the continuing Cyprus crisis discussed earlier.

The international law concepts of exclusive economic zone and the continental shelf grants certain privileges concerning the exploration and exploitation of energy resources to coastal states. Therefore, the delimitation of these maritime zones represents a significant national economic interest on the part of these states. At the same time, it is considered a matter of sovereignty and national independence by those same states. International law rules regarding delimitation are far from clear and concrete. They are based on the principle of equitable solution and the negotiation and conclusion of international agreements. Greece claims a full exclusive economic zone of 200 nautical miles to its easternmost islands in Eastern Mediterranean; Southern Cyprus similarly claims an exclusive economic zone of 200 nautical miles despite being very close to the southern coast of Turkey. In summary, the extent of maritime zones of the islands has become the most critical element of the dispute. The 1982 United Nations Convention on the Law of the Sea in Article 121 states the following: " "the territorial sea, the contiguous zone, the exclusive economic zone and the continental shelf of an island are determined in accordance with the provisions of this Convention applicable to other land territory." Accordingly, islands are subject to the principle of the equitable solution without any question.

The concept of equity has been analyzed and explained by the ICJ case law and has not, overall, consisted of numerus clausus criteria. However, constructing a provisional equidistance line seems the first step, and adjusting this line according to relevant circumstances should then form the second step. Finally, according to the case-law of the ICJ, validating that the line thus adjusted would not lead to an inequitable result by comparing the ratio of coastal lengths with the ratio of relevant maritime areas is necessary. In the case of Serpents' Island, the island's location in the area of delimitation has been considered by the ICJ. The court decided that it should not affect the delimitation other than that stemming from the role of the 
12-nautical-mile arc of the island's own territorial sea. As with Serpents' Island, certain easternmost Greek islands, such as Crete and Rhodes, lying alone and far from the mainland, are not one of a cluster of fringe islands constituting "the coast" of Greece. Therefore, it would be inappropriate to consider those islands to construct a provisional equidistance line between the coasts of Turkey and Greece. 


\section{Türkiye ile Avrupa Birliği Arasında Doğu Akdeniz Meselesine İlişsin Güncel Siyasi Gelişmeler ve Meselenin Uluslararası Hukuk Boyutu}

\section{Doğu Akdeniz Meselesinin Arka Planı}

\section{A. Doğu Akdeniz’in Stratejik Önemi}

Doğu Akdeniz, tarihte de günümüzde de coğrafi konumu gereği stratejik açıdan önemli bir bölge olmuştur. Arap Yarımadası, Orta Doğu ve Avrupa ülkelerini birbirine bağlaması bakımından ticaret için önemli bir geçiş güzergâhı teşkil etmiş ve Süveyş Kanalı'nın açılması sonrası Avrupa ve Uzak Doğu arasında âdeta kestirme bir yol olarak kullanılmıştır. ${ }^{1}$ Ayrıca askeri bakımdan da oldukça stratejik bir bölge olması hasebiyle pek çok ülke bu bölgede bir askeri üs edinme çabası içinde olmuştur. ${ }^{2}$ Ticari ve askeri öneminin yanı sıra, barındırdığı doğal kaynak rezervleri açısından da Doğu Akdeniz paylaşılamayan bir bölge olmuştur. ABD Jeolojik Araştırmalar Merkezi’nin 2010 yılında yaptığ iki farklı çalışmada, Levant havzasında 1,7 milyar varil petrol, 3.5 tcm doğal gaz, Nil deltasında ise 1,8 milyar varil petrol ve 6,3 tcm doğal gaz bulunduğu tahmin edilmektedir. ${ }^{3} 2009$ yılı sonrasındaki 10 yıl içerisinde bölgede keşfedilen petrol ve doğalgaz miktarı ise $2500 \mathrm{bcm}$ olarak saptanmıştır. ${ }^{4}$ Son on yılda keşfedilen miktarlarla birlikte hâlen arama yapılan bölgelerin mevcudiyeti de göz önünde bulundurulduğunda, dünya petrol ve doğalgaz kaynaklarının çok önemli bir kısmının Doğu Akdeniz'de bulunması olasıllı̆ı ortaya çıkmıştır. Bu durum, son zamanlarda bölgede yaşanan siyasi gerilimin sebebini de bir yönüyle ortaya çıkarmaktadır.

Doğu Akdeniz'de kıyısı bulunan devletler bakımından keşfedilen hidrokarbon kaynaklarının önemi hak sahibi olmaları bakımından büyüktür. Fakat bölgedeki deniz yetki alanlarının sınırlandırılması noktasındaki uyuşmazlıklar, hidrokarbon kaynakları üzerindeki haklarını da etkilediğinden, keşifler arttıkça bölgedeki sınırlar da daha önemli bir hâl almış ve uyuşmazlıkları tetiklemiştir. Deniz yetki alanlarının sınırlandırılması bakımından problemlerin çözülmesi hâlinde keşfi yapılan hidrokarbon kaynakları üzerindeki hak sahipliği problemi de çözülecektir. Fakat sınırları ihtilaflı birden fazla bölge bulunmaktadır. Türkiye bakımından bu bölgelerin başında Kıbrıs ve çevresi gelmektedir. KKTC'nin devlet olarak tanınmamasının bir sonucu olarak deniz yetki alanlarının da tanınmaması ve GKRY'nin adanın tek egemen devleti gibi tasarruflarda bulunması ihtilafi beslemektedir. Ayrıca Yunanistan'ın

Süveyş Kanalı’nın açılması ile Avrupa ve Uzakdoğu arasındaki rota, yaklaşık 7000 deniz mili kadar kısalmıştır. Bkz. Cihat Yayc1, 'Doğu Akdeniz'de Deniz Yetki Alanlarının Paylaşılması Sorunu ve Türkiye' (2012) 4 Bilge Strateji 1, 4

İslam Safa Kaya, 'Uluslararası Deniz Hukuku Çerçevesinde Doğu Akdeniz'deki Petrol Ve Doğalgaz Kaynakları ile Türkiye'nin Hukuki Konumu' (PhD, Kırıkkale Üniversitesi 2014) 142 ; Yaycı (n 1) 6

Sohbet Karbuz, 'Doğu Akdeniz'de ne Kadar Doğal Gaz Var?' (2019) No.12 Bilkent Enerji Notları, < https://drive.google. com/open?id=1DLMx9kmHcB2P2cTz73jp7yEmooehSDj9 > Erişim tarihi 22 Kasım 2020.

4 ibid 3; Ana Stanic ve Sohbet Karbuz, 'The Challenges Facing Eastern Mediterranean Gas and How International Law Can Help Overcome Them' (2020) Journal of Energy \& Natural Resources Law <https://doi.org/10.1080/02646811.2020.1816 739> Erişim tarihi 22 Kasım 2020. 
uluslararası hukuka aykırı biçimde adaları ileri sürerek deniz yetki alanlarını arttırma politikası, Türkiye ile arasındaki deniz yetki alanlarının sınırlandırılması konusunda hâlen süregelen çözümsüz bir problem yaratmıştır.

\section{B. Kıbrıs Meselesi}

Doğu Akdeniz'deki politik gerilimin en önemli sebeplerinden biri de Kıbrıs meselesidir. 1923 yılı öncesinde adada fiilen hâkimiyeti süren İngiltere, Lozan Barış Antlaşması ile bu durumu resmileştirmiştir. ${ }^{5} 1923$ yılında başlayan İngiltere hâkimiyetinden Kıbrıs Cumhuriyeti'nin kuruluşuna kadar geçen süre zarfinda, adadaki Rumlar Yunanistan ile birleşme amacını ifade eden Enosis emeli etrafında silahlanarak örgütlenmiş, Türkler ise adanın taksimi hususunda ısrar etmiş ve haklarını savunmuşlardır. ${ }^{6} \mathrm{Bu}$ süreçte her iki taraftan çok sayıda sivil yer değiştirmek zorunda kalmıştır. $^{7}$ Adadaki hayatı birçok yönden felç eden çatışmaların yaygınlaşması sonucu barış için girişimlerinde bulunulmuş ve 1959 'da Türkiye, Yunanistan ve İngiltere'nin de katıldığ görüşmeler sonucu 19 Şubat 1959'da Londra'da Zürih ve Londra Antlaşmaları olarak bilinen, Kıbrıs Cumhuriyeti'ni kuran antlaşma ile birlikte Garanti ve İttifak Antlaşmaları imzalanmıştır. ${ }^{8}$ Türkiye, Yunanistan ve İngiltere, Kıbrıs'ın kurucu antlaşması ile birlikte garanti antlaşmasında garantör devletler sıfatıyla imzacı olmuşlardır. ${ }^{9}$ Antlaşmaların imzalanması öncesinde Kıbrıs meselesinin Birleşmiş Milletler (BM) gündemine taşınması için Yunanistan tarafından 1954 yılında girişimlerde bulunulmuşsa da, konunun gündeme alınması Kıbris Cumhuriyeti'nin kurulması ve BM'ye üye olmas1 sonrasında, 1964 yılında gerçekleşmiştir. ${ }^{10}$ Fakat, çözüm için taraflarca somut adımlar atılmamış ve BM tarafindan sunulan çözüm önerileri de sonuç vermemiştir.

Kıbrıs Cumhuriyeti'nin kurulmasıla Enosis ve taksim emelleri rafa kaldırılarak tek bir devlet çatısı altında, Türkçe ve Rumca resmi dil kabul edilerek, her iki tarafın aynı anayasaya tâbi biçimde birlikte yaşaması öngörülmüşse de taraflar arasındaki ihtilaf varlığını sürdürmüştür. ${ }^{11}$ Rum kesimi tarafından Londra ve Zürih Antlaşmaları ve ortak anayasa hükümlerinde öngörülen siyasi eşitlik ilkesine aykırı biçimde adadaki Türk nüfus aleyhine politikalar izlenmeye başlanmış; taraflar arasındaki tansiyon tekrar yükselmiştir. 1963 yılında Rum kanadının lideri olan Makarios,

\footnotetext{
Bahadır Bumin Özarslan, 'Uluslararası Hukuk ve Avrupa Birliği Hukuku Açısından Kıbrıs Sorunu' (PhD, Dokuz Eylül Üniversites 2006) 9; Müge Vatansever, ‘Kıbrıs Sorununun Tarihi Gelişimi’ (2010) 12 Dokuz Eylül Üniversitesi Hukuk Fakültesi Dergisi 1497.

6 Harry Tzimitras ve Mete Hatay, 'The Need For Realism: Solving The Cyprus Problem Through Linkage Politics' (2016) Turkey Project Policy Paper $9<$ https://www.brookings.edu/wp-content/uploads/2016/10/turkey_20161005_cyprus_ problem.pdf> Erişim tarihi 23 Kasım 2020.

ibid.

Özarslan (n 5) 10.

Antlaşma metinleri için bkz. 'Kıbrıs'<http://www.mfa.gov.tr/kibris.tr.mfa> Erişim tarihi 23 Kasım 2020.

10 Hasan Duran, 'BM ve AB Çerçevesinde Kıbrıs Sorununa Güncel Bir Bakış’ (2008) 21 Dumlupınar Üniversitesi Sosyal Bilimler Dergisi 119.
}

11 ibid 122. 
Kıbrıs Cumhuriyeti'ni kuran Zürih ve Londra Antlaşmalarının her ikisini de tek taraflı olarak feshettiğini açıklamıştır. ${ }^{12}$ Açıklama sonrasında EOKA örgütü tarafından Kıbrıs Türklerine karşı başlatılan silahlı saldırılar tarihe Kanlı Noel olarak geçmiştir. Bu olaylar üzerine Türkiye'nin girişimleri sonucunda BM, 4 Mart 1964 tarih ve 186 sayılı kararı ile bölgeye barış gücü askerlerini konuşlandırmıştır. ${ }^{13}$

1974 Temmuz ayında Rum lider Makarios'un darbe sonucu devrilmesi sonrasi Türkiye, adanın bağımsızlığından duyduğu endişe sebebiyle ve Türklerin emniyetini sağlama amacıyla, garanti antlaşmasından aldığı yetkiye dayanarak ilk askeri müdahalesinde bulunmuştur. ${ }^{14}$ Ağustos ayında Türkiye'nin ikinci müdahalesi gerçekleşmiş, sonrasında ada ikiye bölünmüş ve Türkler kuzeyde kalmıştır. İlerleyen süreçte Türkiye'den bölgeye önemli bir nüfus göçü yaşanmış ve ayrıca adanın güneyinde kalan Türkler de mübadele yoluyla Kuzey'e getirilmişlerdir. ${ }^{15} \mathrm{Bu}$ taksimin ardından 1983 yılında Kuzey Kıbrıs Türk Cumhuriyeti (KKTC) bağımsızlık ilan etmişse de yalnızca Türkiye tarafından bir devlet olarak tanınmıştır. Zira bağımsızlık deklarasyonu sonrasında BM Güvenlik Konseyi derhâl toplanıp duruma ilişkin 541 nolu kararı alarak deklarasyonun 1960 yılı antlaşmalarını ihlal eder nitelikte olduğunu ve dolayısıyla geçersiz olduğunu, böyle bir devlet kurma çabasının durumu ancak daha da kötüleştireceğini dile getirmiştir. ${ }^{16}$ BM'nin Rum kesimi lehine tavrını açıkça belli etmesi, KKTC'nin uluslararası toplum nezdinde haklarını savunurken daha zayıf bir konuma düşmesine sebep olmakla birlikte, Güney Kıbrıs Rum Yönetimi'nin (GKRY) konumunu güçlendirmiştir. Nitekim GKRY, 541 sayılı karar sonrasında adanın tamamında egemenlik iddia etmeye devam etmiş ve KKTC'nin aksine, birçok devlet tarafindan da tanınmıştır. Ayrıca 1990 yılında adanın tek egemen devleti iddiasıyla Avrupa Birliği (AB) üyeliği için başvuru yapmıştır. AB, GKRY'nin birliğe kabulü için adada siyasi bir çözümün gerektiğini belirtmişse de bu çözüm 2004 yılına kadar sağlanamazsa GKRY'nin $\mathrm{AB}$ üyeliğine kabul edileceğini açıklamıştır. ${ }^{17} \mathrm{Bu}$ açıklama sonrası adadaki siyasi çözüm arayışı alevlenmiş ve 2002 yılında dönemin BM Genel Sekreteri Kofi Annan tarafindan hazırlanan "Annan Planı" tarafların incelemesine sunulmuştur. Plan taraflarca müzakere edildikten sonra referandum yapılmış, Rum kesimi çoğunluk üzere planı reddederken, Türk tarafı çoğunlukla onaylamıştır. Rum kesiminin planı reddetmesi adadaki durumu daha kötü bir hâle getirmiş ve dünya liderleri referandum sonucundan ötürü duydukları hayal kırıklı̆̆ını tepki olarak dile

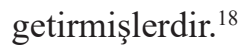

\footnotetext{
Özarslan (n 5) 11.

BM Güvenlik Konseyi'nin 186 nolu kararı (4 Mart 1964) UN Doc S/RES/186.

Bu müdahalenin antlaşmadan alınan yetkiyle yapıldığı I. Cenevre Konferansı'nda da dile getirilmiştir. Bkz. Özarslan (n 5) 12. 
GKRY, 1 Mayıs 2004 tarihinde Kıbrıs adasının tamamını temsilen AB üyeliğine de kabul edilmiştir. Böylelikle KKTC, AB üyesi devletlerce de yok sayılmıştır. Türkiye'nin buna karşılık yaptığı açıklamada şu ifadeler yer almıştır;

“1 Mayıs 2004 tarihinde AB'ye katılacak olan Rumlar, Kıbrıs Türklerini veya Klbrıs’ın tamamını temsil etmeye yetkili olmadıkları gibi, eşit statüye sahip Kıbrıs Türkleri veya Kıbrıs Adası'nın tamamı üzerinde yetki veya egemenlikleri de bulunmamaktadır. "Kıbrıs Cumhuriyeti" Kıbris Türklerine zorla empoze edilemez. Kendi anayasal düzenleri altında ve kendi sınırları içerisinde örgütlenmiş bulunan Rumlar, Kıbrıs Türklerini veya Kıbrıs'ın tamamını temsil eden yasal hükümet olarak kabul edilemez."

Kıbrıs’ta Güney ve Kuzey’de hâlihazırda iki farklı devlet varlığını sürdürüyor olsa da GKRY'nin AB ve BM tarafindan tanınıyor olmasına karşın KKTC'nin yalnızca Türkiye tarafindan tanınması ve BM desteğinden de yoksun olması, Doğu Akdeniz krizinde savunmasız kalmasına sebep olmaktadır. Zira GKRY uluslararası toplum nezdinde hukuken bir devlet olarak tanınmasının yanı sıra Kıbrıs'ta meşru tek egemen olarak kabul edilmesinden aldığı güçle deniz yetki alanlarının sınırlandırılması hususunda da KKTC'yi yok saymakta ve adanın tamamının deniz yetki alanlarında hak iddia etmektedir.

\section{Deniz Yetki Alanlarına İlişkin İhtilaflar ve Enerji Kaynaklarının Tasarrufu}

Doğu Akdeniz'de hâlihazırda keşfedilmiş önemli hidrokarbon kaynakları, Nil deltası ve Levant havzasında bulunmaktadır. Mısır'ın yetki alanı içinde bulunan Zohr, İsrail'in deniz yetki alanları içerisinde kalan Leviathan, Tamar ve GKRY ile Türkiye arasındaki ihtilaflı bölgede yer alan Afrodit bölgelerinde ağırlıklı olarak doğal gaz rezervlerinin yanı sıra petrol rezervleri de bulunmaktadır.

19 'TC Dışişleri Bakanlığı'nın GKRY’nin AB Üyeliği ile ilgili Açıklaması' (1 Mayıs 2004) <http://www.mfa.gov.tr/tcdisisleri-bakanligi_nin-gkry_nin-ab-uyeligi-ile-ilgili-aciklamasi-_1-mayis-2004_.tr.mfa> Erişim tarihi 23 Kasım 2020. 


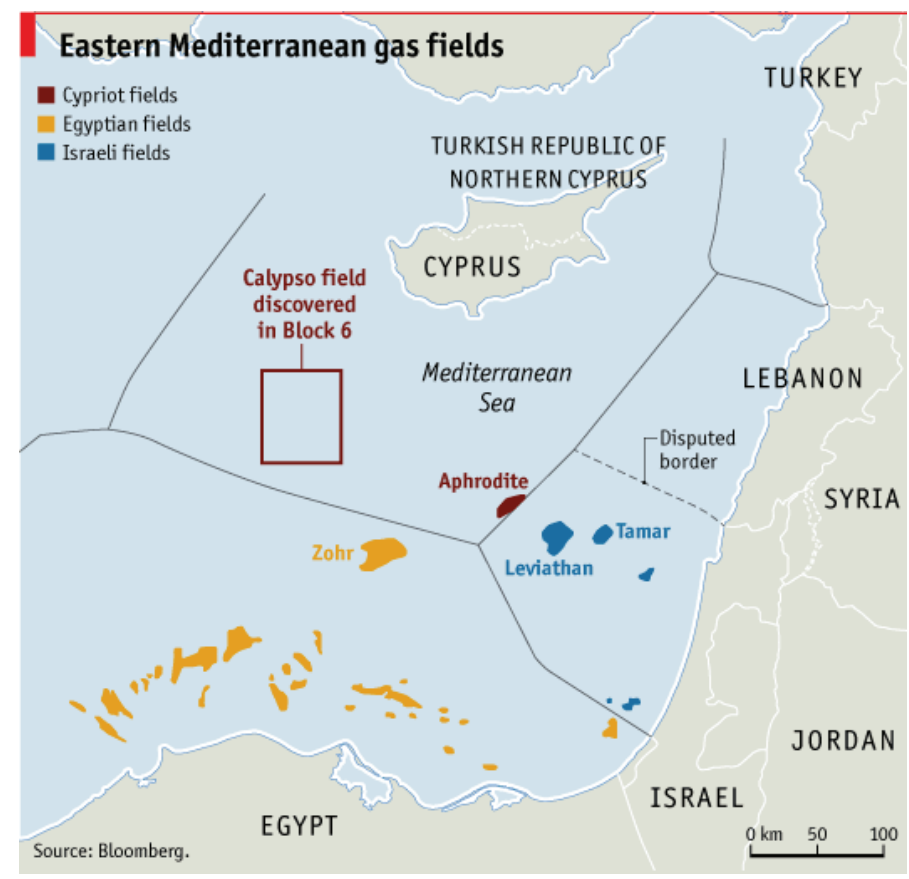

Şekil 1. Doğu Akdeniz'de bulunan Hidrokarbon rezervleri

Kaynak: The Economist, 'Egypt holds keys to East Mediterranean gas' (2018) https://www. eiu.com/industry/article/1466463730/egypt-holds-keys-to-east-mediterranean-gas/2018-02-23

Erişim tarihi 25 Kasım 2020.

Bölgedeki enerji kaynakları konusunda yaşanan krizlerin temelinde de devletlerin deniz yetki alanlarının sınırları konusundaki belirsizlikler ve anlaşmazlıklar yatmaktadır. $^{20} \mathrm{Bu}$ anlaşmazlıklar bölgede varlığı tahmin edilen hidrokarbon kaynaklarının keşfi ve sondaj faaliyetlerini zorlaştırdığından, ekonomi de olumsuz etkilenmektedir. Yakın zamanda Türkiye'nin kendi kıta sahanlığı ve KKTC'nin Türkiye Petrolleri Anonim Ortaklığı'na (TPAO) ruhsat verdiği araştırma bölgelerine gönderdiği sondaj gemilerinin faaliyetleri de Yunanistan ve GKRY'nin muhalefetinden ötürü tansiyonun yükselmesine sebep olmuştur. Bölgedeki temel problem deniz yetki alanlarının belirlenmesi olduğundan, öncelikle bu hususa değinmek yerinde olacaktır.

$\overline{20}$ Stanic ve Karbuz (n 4) 20. 


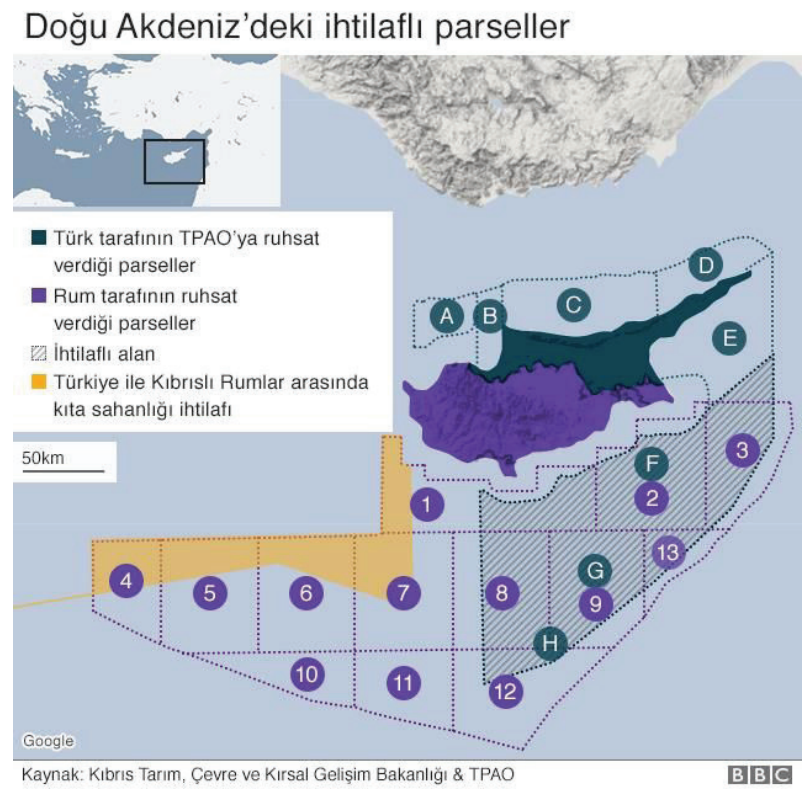

Şekil 2. Sondaj çalışmalarına konu olan KKTC ve GKRY arasındaki ihtilaflı bölge

Kaynak: BBC 'Doğu Akdeniz: Kıbrıs açıklarında doğalgaz arama krizi nasıl başladı, hangi ülke ne istiyor?' (2019) https://www.bbc.com/turkce/haberler-dunya-48225246 erişim tarihi 25 Kasım 2020.

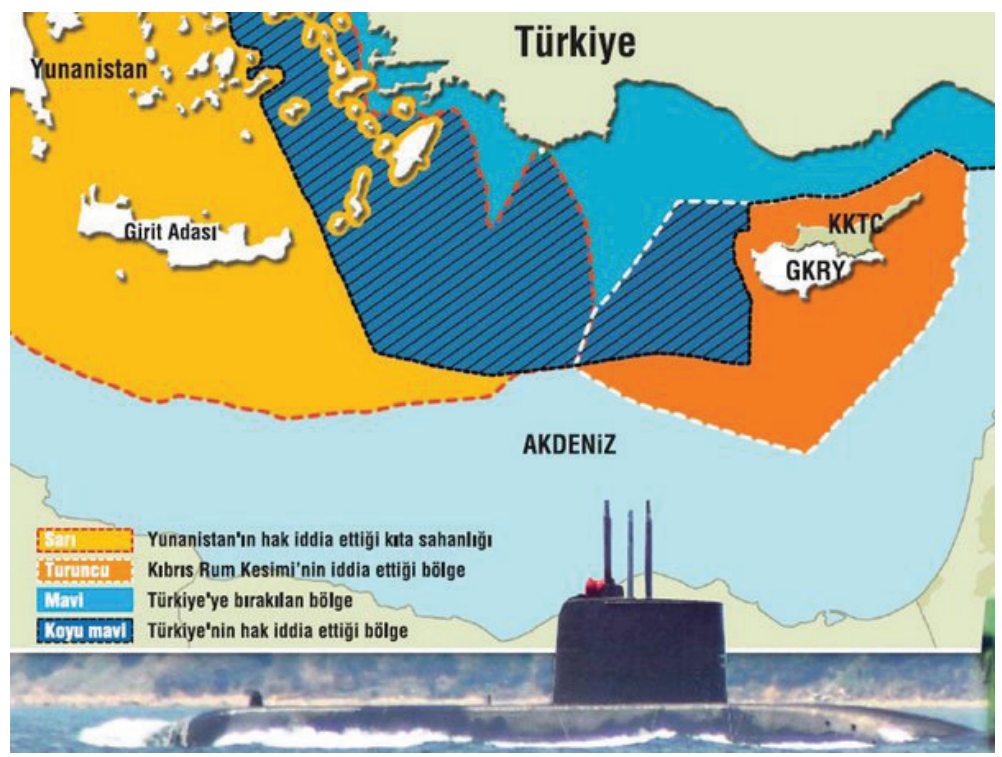

Şekil 3. Yunanistan ve GKRY'nin Muhalefet Ettiği Deniz Alanları

Kaynak: https://im.haberturk.com/2011/09/23/ver1317214041/672328_3190ffc4ab74718d5e6 b2243727ea500.jpg Erişim tarihi 25 Kasım 2020. 
Görseller üzerinde işaretli alanlardan da anlaşılabileceği üzere, Türkiye'nin Doğu Akdeniz'de bulunan deniz yetki alanlarının bir kısmı, Yunanistan ve GKRY muhalefeti ile karşı karşıyadır. Yunanistan, adaları sebep göstererek maksimalist bir yaklaşımla deniz yetki alanlarını genişletme yönünde bir politika izlerken; GKRY de KKTC'yi yok sayarak adanın tümüne egemenmişçesine deniz yetki alanları üzerinde tasarrufta bulunmakta ve ayrıca KKTC'den bağımsız olarak Türkiye ile çakışan alanlar üzerinde hak iddia etmektedir. Bilindiği üzere, Türkiye ve Yunanistan arasında deniz yetki alanlarına ilişkin anlaşmazlık yeni değildir. Fakat Doğu Akdeniz'de hidrokarbon rezervlerinin keşfedilmesi sonrasında bölgenin önem kazandığı ve dolayısıyla deniz yetki alanları konusundaki anlaşmazlıkların daha karmaşı bir problem hâline geldiği söylenebilecektir. Bölgede ilk keşifler, 2009-2010 yıllarında İsrail'in münhasır ekonomik bölgesi içinde kalan Tamar ve Leviathan bölgelerinde yapılmıştır. ${ }^{21} 2011$ 'de ise GKRY'nin iddia ettiği münhasır ekonomik bölgesi içinde kalan Afrodit bölgesinde hidrokarbon rezervleri keşfedilmiştir. ${ }^{22} \mathrm{Bu}$ keşifle birlikte Türkiye ile Yunanistan ve GKRY bloğu arasındaki gerginlik de giderek artmıştır.

GKRY, deniz yetki alanlarının belirlenmesi hususunda ilk hamlesini, 2003 yılında Mısır ile münhasır ekonomik bölge (MEB) alanlarının sınırlandırılmasına ilişkin antlaşma imzalayarak yapmıştır. ${ }^{23}$ Bir y1l sonra $\mathrm{AB}$ üyeliğine kabulü arefesinde 2003 yılından itibaren geçerli olmak üzere MEB ilan etmiştir. ${ }^{24}$ Daha sonra 2007 yılında Lübnan ile, 2010 yılında ise İsrail ile MEB sınırlama antlaşmaları yapmıştır. ${ }^{25}$ Suriye ile henüz bir antlaşma yapmış olmasa da, 2001 yılında birtakım müzakerelere başlandığı bilinmektedir. ${ }^{26}$ Nitekim yakın zamanda GKRY'nin Suriye' deki diplomatik misyonunun tekrar faaliyete geçeceği gündeme gelmiştir. ${ }^{27}$

21 Faruk Can, 'Doğu Akdeniz'de Ne Kadar Doğal Gaz Var?' (Euronews, 31. 12. 2019) <https://tr.euronews.com/2019/12/31/ dogu-akdeniz-ne-kadar-dogal-gaz-rezervi-var-en-buyuk-payi-hangi-ulkeler-alacak> Erişim tarihi 26 Kasım 2020.

22 GKRY, AB'ye üye olarak kabul edilmesinin kısa bir süre öncesinde MEB ilan etmiştir. Afrodit bölgesi de ilan edilen MEB alanı içerisinde yer almaktadır. Bkz. 'A Law to Provide for the Proclamation of the Exclusive Economic Zone By Republic of Cyprus’ (2 Nisan 2004) <https://www.un.org/Depts/los/LEGISLATIONANDTREATIES/PDFFILES/cyp_2004_eez_ proclamation.pdf $>$ Erişim tarihi 27 Kasım 2020.

23 Antlaşma Metni için bkz. 'Agreement Between The Republic of Cyprus and the Arab Republic of Egypt on the Delimitation of the Exclusive Economic Zone'(UN, 2003)<https://www.un.org/Depts/los/LEGISLATIONANDTREATIES/PDFFILES/ TREATIES/EGY-CYP2003EZ.pdf> Erişim tarihi 27 Kasım 2020.

24 'A Law To Provide The Proclamation Of The Exclusive Economic Zone By Republic Of Cyprus' (2004) <https://www. un.org/Depts/los/LEGISLATIONANDTREATIES/PDFFILES/cyp_2004_eez_proclamation.pdf> Erişim tarihi 27 Kasım 2020.

25 Lübnan ile yapılan antlaşma Lübnan iç hukukunda onaylanmamıştır. İsrail ile yapılan antlaşma metni için bkz. 'Agreement Between The Government of the State of Israel and the Government of the Republic of Cyprus on the Delimitation of the Exclusive Economic Zone' (UN, 2010) <https://www.un.org/Depts/los/LEGISLATIONANDTREATIES/PDFFILES/ TREATIES/cyp_isr_eez_2010.pdf> Erişim Tarihi 27 Kasım 2020.

26 Yaycı (n 1) 17, Fuat Aksu, "Doğu Akdeniz Deniz Yetki Alanları Sorunu ve Türkiye-AB İlişkileri”, in Sertaç Hami Başeren (eds), Doğu Akdeniz'de Hukuk ve Siyaset, (A.Ü. SBF Yay., 2013) 163, Ömer Lütfi Taşçığlu, "GKRY'nin Münhasır Ekonomik Bölge Anlaşmaları ve Petrol ve Doğal Gaz Arama Çalışmaları” (2018) 4 Social Sciences Studies Journal 5699.

27 Giorgio Cafiero, 'Why is Greece mending relations with Assad?' ( Middle East Eye, 5 Ağustos 2020) <https://www. middleeasteye.net/opinion/greece-syria-assad-mending-relations-turkey-threat $>$ Erişim tarihi 26 Kasım 2020. , Paul Antonopoulos, 'Cyprus is reopening relations with Syria' (Greek City Times, 13 May1s 2020) <https://greekcitytimes. com/2020/05/13/cyprus-is-reopening-relations-with-syria> Erişim Tarihi 26 Kasım 2020. 
Bu gelişmelerle birlikte 2007 yılında önceden ilan ettiği MEB'i parsellere ayırarak araştırma sahaları oluşturmuş, sonrasında başvuru almaya başlamış ve Afrodit bölgesini de içeren 12 numaralı sahadaki araştırma hakları Noble Energy şirketince satın alınmıştır. ${ }^{28}$ Noble Energy, bölgedeki sondaj faaliyetlerini gerçekleştirmek üzere İsrail menşeli Delek Group Şirketi ile ortaklık kurmuş, sondaj faaliyetlerinin Türkiye'nin müdahalesinden korunması için de GKRY ve İsrail arasında birtakım anlaşmalar yapılmıştır. Bu anlaşmalar çerçevesinde İsrail'in GKRY'den askeri üs talep ettiği bilinmektedir. ${ }^{29}$

Doğu Akdeniz'de Türkiye bakımından gerginliği tırmandıran diğer bir olay, 2015 yılında AB Ortak Çıkar Projeleri arasına dahil edilen EastMed boru hattı projesidir. ${ }^{30}$ Doğu Akdeniz'de GKRY ve İsrail'in yetki alanları içerisinde kalan bölgelerden çıkarılan doğal gazın Yunanistan ve İtalya üzerinden Avrupa’ya taşınmasını ve böylece enerji ihracatında Türkiye'den bağımsız politikalar izlenebilmesini sağlamayı amaçlayan bu projenin temelleri 2015 yılında atılmış, 2020 yılı başında da hükümetler nezdinde Atina'da imzalanan sözleşme ile resmileşmiştir. ${ }^{31}$

Türkiye'nin Doğu Akdeniz'deki hakları aleyhine atılan adımlar ve 2011 yılında GKRY tarafindan adanın güneyinde sondaj çalışmalarına başlanması sebebiyle, Türkiye ve KKTC arasında 21 Eylül 2011 tarihinde kıta sahanlığı sinırlandırma antlaşması imzalanmıştır. ${ }^{32}$ Antlaşmanın amacının bölgede sondaj çalışmalarına başlamak olduğu bakanlıkça açıklanmıştır. ${ }^{33}$ Nitekim ilerleyen süreçte Türkiye, denizlerde sismik araştırma yapmak ve sondaj faaliyetleri yürütmek amacıyla 2012 yılında Barbaros Hayrettin Paşa, 2017 yılında MTA Oruç Reis sismik araştırma gemilerini, 2017 ve sonrasinda ise Fatih, Yavuz ve Kanuni sondaj gemilerini TPAO envanterine katmıştır. ${ }^{34} \mathrm{Bu}$ süreçte GKRY ise Total, Exxon Mobil, ENI gibi dünya devi petrol şirketlerine deniz yetki alanlarında toplamda 9 parsel üzerinde arama ve sondaj yapmak üzere ruhsat vermiştir. ${ }^{35}$ TPAO ise Türkiye ve KKTC arasında yapılan antlaşma sonrası KKTC'den 7 adet deniz, 2 adet kara ruhsat alanı

\footnotetext{
Yaycı (n 1) 18.

Taşçı̆̆lu (n 26) 5700 .

'Eastmed' (2020)<http://www.igi-poseidon.com/en/eastmed> Erişim Tarihi 28 Kasım 2020.

Angeliki Koutantou, 'Greece, Israel, Cyprus sign EastMed gas pipeline deal' (Reuters, 2 Ocak 2020) https://www.reuters. com/article/us-greece-cyprus-israel-pipeline-idUSKBN1Z10R5 Erişim tarihi 28 Kasım 2020.

32 'Türkiye Cumhuriyeti ile Kuzey Kıbrıs Türk Cumhuriyeti Arasında Akdeniz'de Kıta Sahanlığı Sınırlandırılması Hakkında Anlaşmanın Onaylanmasının Uygun Bulunduğuna Dair Kanun' (12.07.2012) < https://www.resmigazete.gov.tr/ eskiler/2012/07/20120712-3.htm> Erişim tarihi 26 Kasım 2020.

33 'Türkiye - KKTC Kıta Sahanlığı Sınırlandırma Anlașması İmzalanmasına İlișkin Dıșişleri Bakanlığı Basın Açıklaması' (21 Eylül 2011) <http://www.mfa.gov.tr/no_-216_-21-eylul-2011-turkiye-_-kktc-kita-sahanligi-sinirlandirma-anlasmasiimzalanmasina-iliskin-disisleri-bakanligi-basin-ac_tr.mfa> Erişim tarihi 26 Kasım 2020.

34 Murat Temizer, 'Türkiye'nin Denizlerdeki Enerji Filosu' (AA, 22 Ağustos 2020) <https://www.aa.com.tr/tr/ekonomi/ turkiyenin-denizlerdeki-enerji-filosu/1949802> Erișim tarihi 26 Kasım 2020.

35 'Granted Licences' <http://www.mcit.gov.cy/mcit/hydrocarbon.nsf/page16_en/page16_en?OpenDocument> Erişim tarihi 27 Kasim 2020.
} 
almış ve sondaj faaliyetlerine başlamıştır. ${ }^{36} 2013$ yılında Barbaros Hayrettin Paşa ile başlayan sismik araştırma faaliyetleri, filoya eklenen diğer gemilerle birlikte giderek hızlanmış GKRY'nin muhalefeti ile bölgede tansiyonu yükseltmiştir. 2019 yılında GKRY tarafindan BM'ye gönderilen mektupta, KKTC'nin bir devlet niteliği taşımadığı dolayısıyla adanın deniz yetki alanlarında hak sahibi olmadığı ve buna bağlı olarak da arama ruhsatı veremeyeceği, bu sebeple de bu ruhsatlara dayalı sondaj faaliyetlerinin hukuk dışı olduğu ileri sürülmüştür. ${ }^{37}$ Ayrıca Türkiye'nin kendi kıta sahanlı̆̆g ile GKRY'nin ilan ettiği MEB alanlarının çakışma hâlinde olduğu ve Şekil 2 üzerinde görülebilecek olan 7 numaralı blokta Yavuz gemisinin yaptığı sondaj çalışmaları da GKRY tarafından başka bir mektupta hukuk dışı olarak nitelenerek BM'ye bildirilmiştir. ${ }^{38}$

Türkiye, 2011 y1lına kadar Doğu Akdeniz'de herhangi bir devletle deniz yetki alanlarının sınırlandırılmasına ilişkin bir antlaşma yapmamış, 2011'de KKTC ile yaptığ1 anlaşmadan 8 yıl sonra 27 Kasım 2019'da Libya'da BM tarafından da tanınan Ulusal Mutabakat Hükümeti ile Akdeniz'de Deniz Yetki Alanlarının Sınırlandırılmasına İlişkin Mutabakat Muhtırası'nı imzalamıştır. ${ }^{39} \mathrm{Bu}$ antlaşma, mutabakat muhtırası olarak anılsa da, hukuki niteliği bir uluslararası antlaşmadır ve nitekim BM tarafından da tescil edilmiştir. ${ }^{40}$

36 ,KKTC` (TPAO) <https://www.tpao.gov.tr/kktc> Erişim tarihi 27 Kasım 2020.

37 'Letter dated 11 July 2019 from the Chargé d'affaires a.i. of the Permanent Mission of Cyprus to the United Nations addressed to the Secretary-General' Doc.A/73/944 (United Nations 2019) < https://undocs.org/en/A/73/944> Erişim tarihi 28 Kasim 2020

38 'Letter dated 13 November 2019 from the Permanent Representative of Cyprus to the United Nations addressed to the Secretary-General' Doc. A/74/549 (United Nations 2019) < https://undocs.org/A/74/549> Erişim tarihi 28 Kasım 2020.

39 'Türkiye Cumhuriyeti Hükümeti ile Libya Devleti Ulusal Mutabakat Hükümeti Arasında Akdeniz'de Deniz Yetki Alanlarının Sınırlandırılmasına ilişkin Mutabakat Muhtırası' (Resmi Gazete, 7 Aralık 2019) https://www.resmigazete.gov. tr/eskiler/2019/12/20191207-3.pdf Erişim tarihi 28 Kasım 2020.

40 Cüneyt Yüksel ve Deniz Baran, 'Uluslararası Hukukta Doğu Akdeniz Krizi ve Türkiye ile Libya Arasındaki Deniz Yetki Alanlarını Sınırlandırma Mutabakatının Değerlendirilmesi' (2020) 40(1) PPIL https://doi.org/10.26650/ ppil.2020.40.1.0019 Erişim tarihi 28 Kasım 2020. ; 'Certificate of Registration' (UN, 11 Aralık 2019) <https://treaties. un.org/doc/Treaties/2019/12/20191211\%2002-58\%20PM/Other\%20Documents/COR-Reg-56119-Sr-69975.pdf> Erişim tarihi 28 Kasim 2020. 


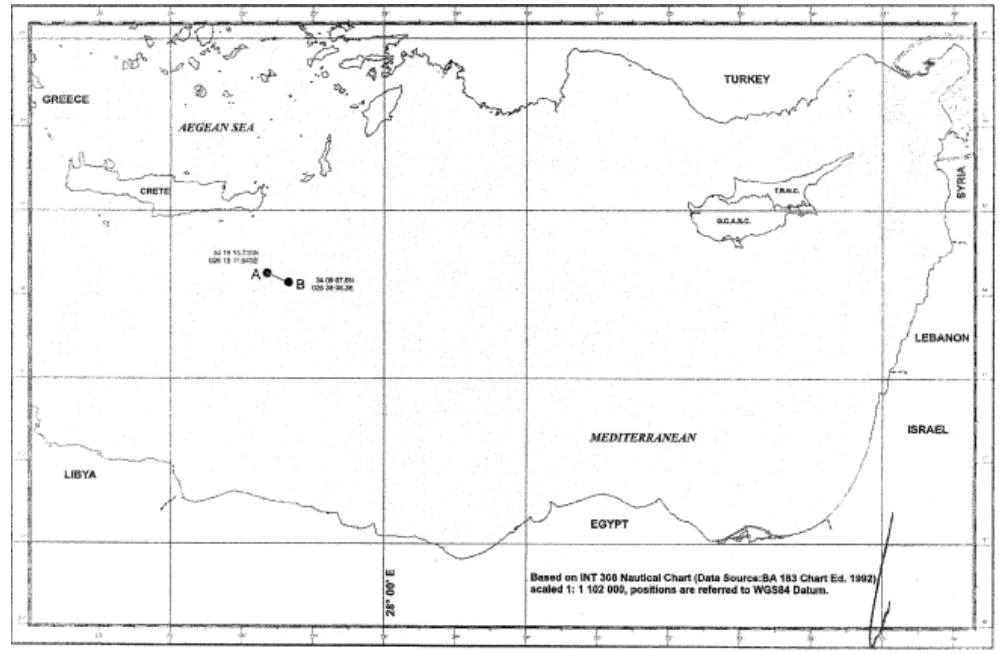

Şekil 4. Türkiye ile Libya arasında yapılan antlaşma ile belirlenen sınır Kaynak: (Resmi Gazete, 07.12.2019) <https://www.resmigazete.gov.tr/ eskiler/2019/12/20191207-3.pdf>

Şekil 3 ve 4 birlikte incelendiğinde aç1kça görülecektir ki Türkiye ve Libya arasında belirlenen sınır, Yunanistan'ın iddia ettiği MEB alanında yer almaktadır. Diğer bir deyişle, Türkiye ve Libya, imzaladıkları antlaşma ile Yunanistan'ın hak iddialarını tanımadıklarını dile getirmişlerdir. ${ }^{41} \mathrm{Bu}$ durum karşısında Yunanistan da kendi iddiaları güçlendirmek amaciyla 6 Ağustos 2020 tarihinde Misır ile deniz yetki alanlarının sınırlandırılmasına ilişkin antlaşma imzalamıştır. $\mathrm{Bu}$ antlaşma ile belirlenen sınır da Türkiye ve Libya arasındaki mutabakat muhtırasında belirlenen sınırların Mısır ve Yunanistan nezdinde tanınmadığını göstermektedir. ${ }^{42}$

Doğu Akdeniz'de Türkiye ve KKTC'ye karşı Yunanistan ve GKRY bloğu arasında yaşanan gelişmeler, bölgede kıyısı bulunan diğer devletlerle birlikte $\mathrm{AB}$ ülkeleri için de oldukça önemli bir hâle gelmiştir. Nitekim AB, EastMed projesinin 2015 yllında $\mathrm{AB}$ programına alınması sonrasında bölgedeki gelişmeleri daha yakından izlemeye başlamış ve hem üye devletler olmaları hem de EastMed projesini yürütmeleri sebebiyle Yunanistan ve GKRY bloğu yanında yer alarak Türkiye aleyhine bir politika izlemeye başlamıştır. Dolayısıyla Doğu Akdeniz'de deniz yetki alanlarının sınırlandırılması ve enerji kaynaklarının tasarrufundan doğan ihtilaflar, $\mathrm{AB}$ düzeyinde

41 Nitekim Türkiye'nin BM’ye kıta sahanlığının sınırlarını bildirme amacıyla gönderdiği 18 Mart 2020 tarihli mektupta yer alan harita da bunu desteklemektedir; 'Letter dated 18 March 2020 from the Permanent Representative of Turkey to the United Nations addressed to the Secretary-General, United Nations General Assembly Doc. A/74/757 (United Nations, 2020) <https://undocs.org/en/A/74/757> Erişim Tarihi 24 Aralık 2020.

42 Sertaç Hami Başeren, 'Mısır-Yunanistan anlaşması ve Türkiye'nin Doğu Akdeniz'deki Uygulamaları' (AA, 26 Ağustos 2020) $<$ https://www.aa.com.tr/tr/analiz/misir-yunanistan-anlasmasi-ve-turkiye-nin-dogu-akdeniz-deki-uygulamalari/1953584> Erişim tarihi 24 Aralık 2020. 
uluslararası boyuta taşınmış ve bu durum Türkiye - AB ilişkileri bakımından yeni bir safhaya gelindiğini göstermiştir.

\section{Türkiye ile AB Arasında Doğu Akdeniz Meselesine İlişskin Güncel Siyasi Gelişmeler}

Doğu Akdeniz' de deniz yetki alanlarının paylaşım mücadelesinin yanında, tarihsel önemi haiz Kıbrıs sorunu ve Adalar meselesinin de içinde olduğu Ege-Akdeniz'de son zamanlarda meydana gelen hadiseler, Türkiye ve Yunanistan arasındaki ikili ilişkiler sınırını aşarak uluslararasılaşma düzeyi artan bir seyir izlemiştir.

Türkiye, GKRY'nin Kıbrıs Cumhuriyeti sıfatıyla tüm adayı kapsayarak diğer devletlerle yaptığg anlaşmaları birden fazla nedene dayanarak hükümsüz kabul ettiğini ifade etmektedir. Birincisi, Kıbrıs Cumhuriyeti'ni tanımadığını, dolayısıyla onun ilan ettiği MEB'in de Türkiye için hükümsüz olduğunu söylemektedir. İkinci olarak Kıbrıslı Rumların adada yaşayan Türk nüfusunu temsil etmediğini dile getirmektedir. Üçüncü olarak ise GKRY'nin tek taraflı olarak yürüttüğ̈̈ keşif faaliyetlerinin adadaki uzlaşma ve yeniden birleşme sürecini sekteye uğrattığını, Kıbrıs sorunu çözüme kavuşana kadar Doğu Akdeniz'deki tek taraflı enerji arama ve sondaj faaliyetlerinin askıya alınması gerektiğini ifade etmektedir. ${ }^{43}$

2010'lu yılların başından itibaren gündeme gelen uyuşmazlıklarda genellikle Yunanistan ve Kıbrıs'1 desteklediğini ifade eden AB Bakanlar Konseyi, 2017'de olumsuz neticelenen Kıbrıs’taki yeniden birleşme görüşmelerinin ve 2016-2020 yılları arasında Türkiye'nin AB ile ilişkilerinin gerilmesine neden olan gelişmelerin de etkisiyle, son yıllarda Türkiye'nin Doğu Akdeniz'de enerji kaynakları arama ve sondaj faaliyetlerini uluslararası hukuka aykırı olmakla itham etmektedir. AB Bakanlar Konseyi, 27 üye ülkenin dışişleri bakanlarının katılımıyla ve topyekün bir şekilde Yunanistan ve Kıbrıs saflarında yer alırken; AB yüksek temsilcisi Josep Borrell, aday ülke statüsünde olan Arnavutluk, Sirbistan, Kuzey Makedonya ve Karadağ'dan da Türkiye'nin faaliyetlerine karşı Konsey’in aldığı kararlar doğrultusunda hareket etmelerini istemiştir. ${ }^{44}$ AB'den Türkiye'ye yönelik getirilen en sert yaptırımlar 15 Temmuz 2019'da Brüksel'de toplanan AB Bakanlar Konseyi tarafından açıklanmıştır. Toplantıda, dönemin AB Dışişleri ve Güvenlik Politikaları Yüksek Temsilcisi Federica Mogherini, Türkiye’nin faaliyetlerini gerilimi aşırı tırmandıran ve "kabul edilemez" hareketler olarak nitelendirmiş ve Türkiye'nin sondaj çalışmalarını "yasa dışı” olarak tanımlanmıştır. Türkiye ile üst düzey siyasi diyalog toplantılarının ve Kapsamlı Havacılık Anlaşması görüşmelerinin askıya

\footnotetext{
43 Sohbet Karbuz, "Geostrategic Importance of East Mediterranean Gas Resources," (2018) Energy Economy, Finance and Geostrategy 249.

44 Volkan Tibet Gur, "Turkey's Isolation From The Regionalization Process in The Eastern Mediterranean: A Case Study of The Eastern Mediterranean Gas Forum (EMGF)” (Master thesis, Ihsan Dogramaci Bilkent University 2020), 90.
} 
alındığını açıklayan Konsey, ayrıca 2020 y1lı için Türkiye'nin AB'den alması beklenen mali yardımlarda azalmaya gidildiğini açıklamış ve Avrupa Yatırım Bankası'ndan Türkiye'ye kredi desteği sağlayıp sağlamamayı tekrar gözden geçirmesini talep etmiştir. Konsey ayrıca Türkiye'nin faaliyetlerine son vermemesi hâlinde seyahat sınırlandırmaları ile faaliyetlerle ilişkilendirilen şahıs ve kurumlara yönelik malvarlıklarının dondurulması gibi yaptırımların da getirilebileceğini dile getirmiştir. ${ }^{45} \mathrm{AB}$ 'de yaşanan bu gelişmelere Ankara'nın cevabı ise Brüksel'in yanlı bir tavır takındığ 1 ve Kıbrıs Türklerinin Ada'nın etrafında keşfedilen doğal kaynaklar üzerindeki hakkını yok saydığı yönünde olmuş, Konsey'in aldığı yaptırım kararlarına rağmen Türkiye'nin arama ve sondaj faaliyetlerine devam edeceği açıklanmıştır. İlerleyen günlerde de geri adım atmayan Türkiye'nin Doğu Akdeniz'deki enerji kaynaklarının paylaşım mücadelesinde attığı en büyük adım sayılabilecek ve meseleye dahil olan tüm devletlerce gündem edilen hamlesi Libya'nın BM nezdinde tanınmış hükümeti ile imzalanan "Deniz Yetki Alanlarının Sınırlandırılmasına İlişkin Mutabakat Muhtırası"dır. ${ }^{46} \mathrm{AB}$ ve üye ülkelerin, Türkiye Büyük Millet Meclisi'nden geçen Libya tezkeresine ve Ulusal Mutabakat Hükümeti ile imzalanan anlaşmalara ilişkin tepkileri gecikmemiştir.

12-13 Aralık 2019 tarihlerinde gerçekleştirilen Avrupa Konseyi toplantısının gündem maddelerinden biri de Libya ile imzalanan anlaşmalar ve Türkiye'nin Akdeniz'deki sondaj faaliyetleri olmuştur. Konsey kararında deniz yetki alanlarının sınırlandırılmasına ilişkin anlaşmanın üçüncü devletlerin egemen haklarını ihlal ettiğine yer verilmiştir. Ayrıca, ilgili anlaşmanın deniz hukuku uyarınca yasal olmadığ ve üçüncü devletler bakımından herhangi bir hukuki sonuç doğuramayacağı bildirilmiş̧ir. Konsey, Türkiye'nin Akdeniz'deki eylemleri karşısında Yunanistan ve Kıbrıs'ın yanında olduğunu belirtmiştiri ${ }^{47}$.

Türkiye ile Libya arasında imzalanan antlaşmanın ardından imzalanan, İsrail ve GKRY'nin ilan ettikleri MEB alanlarından çıkarılacak gazın; Girit üzerinden Yunanistan'a, oradan da İtalya üzerinden Avrupa'nın gaz ağına bağlanmasını öngören EastMed gaz hattı anlaşması ile ilgili olarak, Cumhurbaşkanı Erdoğan bahsi geçen rotada herhangi bir yolun aralarındaki deniz yetki alanları anlaşmasından sonra Libya ve Türkiye devletlerinin rızası alınmaksızın geçemeyeceğini dile getirmiş̧ir. ${ }^{48}$ Buna cevaben, Ocak 2020'nin sonuna gelindiğinde GKRY Dışişleri Bakanı Nikos

45 "No Big Impact on Turkey-EU Relations From Gas Drilling Spat - Pundits," (Sputnik International, 16 Temmuz 2019) $<$ https://sptnkne.ws/7ppp> Erişim tarihi 1 Şubat 2021.

46 Daren Butler and Tuvan Gumrukcu, 'Turkey Signs Maritime Boundaries Deal with Libya amid Exploration Row' (Reuters, 28 Kasım 2019) < https:/www.reuters.com/article/us-turkey-libya/turkey-signs-maritime-boundaries-deal-with-libyaamid-exploration-row-idUSKBN1Y213I> Erişim tarihi 1 Şubat 2021.

47 "European Council Conclusions" (12-13 Aralık 2019) https://www.consilium.europa.eu/en/meetings/europeancouncil/2019/12/12-13/ Erişim tarihi 1 Şubat 2021.

48 “Greece, Israel, Cyprus Sign Deal for EastMed Gas Pipeline," (Kathimerini, 02 Ocak 2020) <https://www.ekathimerini. com/248073/article/ekathimerini/news/greece-israel-cyprus-sign-deal-for-eastmed-gas-pipeline> Erişim tarihi 1 Şubat 2021. 
Christodoulides ile Roma'da bir araya gelen İtalya Dışişleri Bakanı Luigi Di Maio, Libya ile Türkiye arasındaki anlaşmayı diğer devletlerin egemenlik haklarına yönelik kabul edilemez bir uluslararası hukuk ihlali olarak nitelendirmiştir. ${ }^{49}$

Yunanistan, Mısır, GKRY, Fransa ve Birleşik Arap Emirlikleri dışişleri bakanları, Doğu Akdeniz'deki gelişmeleri tartışmak için 11 Mayıs'ta bir telekonferans düzenlemişlerdir. Telekonferans sonrası kamuoyu ile paylaşılan bildiride, Türkiye'nin Doğu Akdeniz'deki eylemleri kınanmış ve Türkiye'nin komşu ülkelerin deniz bölgeleri üzerindeki egemenlik haklarına saygı göstermesi istenmiştir. Beş dışişleri bakanı ayrıca, Türkiye ile Libya arasında imzalanan anlaşmaların devletlerin egemenlik haklarını ihlal ettiğini, deniz hukuku uyarınca yasal olmadığını ve ilgili anlaşmaların herhangi bir yasal sonuç doğuramayacağını iddia etmiştir. ${ }^{50}$

Pandemi nedeniyle toplantılara ara veren AB dişişleri bakanları, 13 Temmuz 2020 tarihinde Brüksel'de bir araya gelmiştir. Toplantının ana gündem maddelerinden birisi de Türkiye ile $\mathrm{AB}$ arasındaki ilişkiler olmuştur. Konsey kararında, Türkiye'nin yasa dışı sondaj faaliyetlerine son vermesi gerektiği ve Türkiye'nin Akdeniz'deki tek taraflı eylemlerinin $\mathrm{AB}$ çıarlarına, üye devletlerin egemenlik haklarına ve uluslararası hukuka aykırı olduğuna yer verilmiştir. ${ }^{51}$

Türkiye'nin Libya ile imzaladığı anlaşmaya karşı 6 Ağustos 2020'de Mısır ile Yunanistan arasında imzalanan deniz yetki alanları sınırlandırma anlaşması sonrası Dendias, bu anlaşmanın Türkiye ile Libya arasında imzalanan mutabakatı hükümsüz bıraktığını iddia etmiştir..$^{52}$ Anlaşmanın ardından, Almanya ve AB'nin diyalog çağrısı üzerine askıya alınan sismik araştırma faaliyetleri yeniden başlatılmıştır. Buna karşılık Türkiye'nin de sondaj faaliyetlerini sürdüreceğini açıklaması üzerine Yunanistan, AB Dışişleri Konseyi'nin acilen toplanmasını talep etmiştir..$^{53}$ Video konferans yöntemiyle 14 Ağustos 2020'de bir araya gelen Konsey, Yunanistan ve Kıbrıs ile tam dayanışma içinde olduğunu tekrardan teyit etmiştir. Bakanlar, Türkiye'nin Akdeniz'deki faaliyetlerinin "husumet ve güvensizlik" yarattığını belirtmiş ve Türkiye'nin tansiyonu düşürmesini istemiştir. Yapılan açıklamada 13 Temmuz 2020 tarihli Dışişleri Konseyi Toplantısı'nın sonuçları hatırlatılmış

\footnotetext{
49 “Italy, Cyprus Say Turkey-Libya Maritime Deal ‘Unacceptable,” (ABC News, 29 Ocak 2020), <https://abcnews.go.com/ International/wireStory/italy-cyprus-turkey-libya-maritime-deal-unacceptable-68618477> Erişim tarihi 1 Şubat 2021.

50 "Joint Declaration Adopted by the Ministers of Foreign Affairs of Cyprus, Egypt, France, Greece and the United Arab Emirates", (11 May1s 2020) <https://www.mfa.gr/en/current-affairs/statements-speeches/joint-declaration-adopted-by-theministers-of-foreign-affairs-of-cyprus-egypt-france-greece-and-the-united-arab-emirates-11052020.html> Erişim tarihi 1 Şubat 2021.

51 "European Foreign Affairs Council Conclusions" (13 Temmuz 2020) <https://www.consilium.europa.eu/en/meetings/ fac/2020/07/13/ > Erişim tarihi 1 Şubat 2021.

52 Noha Elhennawy, 'Egypt, Greece Sign Maritime Deal to Counter Libya-Turkey One' The Washington Post, 6 Ağustos 2020) <https://www.washingtonpost.com/world/middle_east/egypt-greece-sign-maritime-deal-to-counter-libya-turkeyone/2020/08/06/896646a8-d802-11ea-a788-2ce86ce81129_story.html> Erişim tarihi 1 Şubat 2021.

53 'Greece to Request EU Foreign Affairs Council Emergency Meeting amid Tensions over Turkish Drilling', (Euronews, 13 Ağustos 2020), <https://www.euronews.com/2020/08/10/tensions-grow-between-greece-and-turkey-over-exploratorydrilling > Erişim tarihi 1 Şubat 2021.
} 
ve gerilimin düşmemesi hâlinde alınabilecek ilave önlemler için bazı seçenekler üzerinde çalış1lacağı vurgulanmıştır. ${ }^{54}$ Türkiye'nin Doğu Akdeniz'deki yeni sondaj faaliyetleri konusunda yaptığı açıklamada Josep Borrell, “Türk makamlarını, söz konusu faaliyetlere bir an önce son vermeye ve AB ile tam angajman içerisinde ve iyi niyetle kapsamlı diyalogda bulunmaya" çağırmıştır. ${ }^{55}$

TPAO'ya verilen ruhsatlar ile GKRY tarafindan Fransız petrol şirketi Total'e verilen ruhsat alanlarının çakışması Türkiye-Fransa ilişkisini olumsuz etkilemiş olmakla birlikte; Fransa bugün gelinen noktada neredeyse Türkiye ile fiilen savaş hâlindeymiş gibi hareket etmektedir. Cumhurbaşkanı Erdoğan 13 Ağustos 2020'de yaptığı açıklamada tartışmalı sularda faaliyete başlayacak olan sismik araştırma gemisi Oruç Reis'e karşı herhangi bir müdahalenin ağır sonuçları olacağını açıklamıştır. Bir gün evvel Girit açıklarında Yunan ve Türk donanmalarına ait firkateynler arasında çatma $^{56}$ yaşanması üzerine yapılan bu açıklamanın hemen ardından Fransa, Doğu Akdeniz'de Yunanistan ile ortak askeri tatbikatlar yaparak Yunanistan'a askeri destek taahhüdünü dile getirmiştir. ${ }^{57}$ Yaşanan önemli gelişmelerden biri de 10 Eylül 2020'de Korsika Adası'nda bir araya gelen Fransa, Yunanistan, İtalya, Malta, Kıbrıs, İspanya ve Portekiz liderlerinin yaptıkları açıklamalar olmuştur. Toplantıda Türkiye'nin arama ve sondaj faaliyetlerinin “yasa dişı” olduğu tekrar vurgulanarak Türkiye'nin bu faaliyetlere bir son vermesi hâlinde uzlaşmaya hazır olunduğu dile getirilmiştir. ${ }^{58}$ Ocak 2021 'de ise 5 yildır ara verilen, Türkiye ve Yunanistan ile 20022016 yılları arasında gerçekleştirilen ve sonuçsuz kalan istikşafi görüşmelerin 61 . turu için taraflar yeniden masaya oturmuşlardır. Ancak Kıbrıs sorunu çözülmeden Doğu Akdeniz'de bir çözüme varılması pek mümkün görünmemektedir. İstikşafi görüşmeleri takiben 2021 Mart ayında toplanan AB Konseyi de Türkiye'nin Doğu Akdeniz'deki faaliyetlerini hukuk dışı olarak nitelemiş ve derhâl son verilmesi çağrısını yaptırım tehdidiyle birlikte yinelemiştir. ${ }^{59}$

\footnotetext{
54 European External Action Service, 'Video Conference of Foreign Affairs Ministers: Main Outcomes', (14 Ağustos 2020) $<$ https://eeas.europa.eu/headquarters/headquarters-homepage/84103/video-conference-foreign-affairs-ministers-mainoutcomes_en> Erişim tarihi 1 Şubat 2021.

55 European External Action Service, 'Statement by the High Representative/Vice-President Josep Borrell on Renewed Drilling Activities by Turkey in the Eastern Mediterranean', (16 Ağustos 2020) <https://eeas.europa.eu/headquarters/ headquarters-homepage/84111/statement-high-representativevice-president-josep-borrell-renewed-drilling-activitiesturkey_en> Erişim tarihi 1 Şubat 2021.

56 'Turkish and Greek Warships Collide in Eastern Mediterranean,' (Independent, 14 Ağustos 2020) 'https://www.independent.co.uk/news/world/europe/turkey-greece-war-mediterranean-erdogan-ships-collide-a9670416. html > Erişim tarihi 1 Şubat 2021.

57 Clemens Hoffmann, 'Turkey-Greece conflict in eastern Mediterranean is less about gas than vaccum left by Trump,' (The Conversation, 18 Ağustos 2020) <https://theconversation.com/turkey-greece-conflict-in-eastern-mediterranean-is-lessabout-gas-than-vaccuum-left-by-trump-144691> Erişim tarihi 1 Şubat 2021.

58 SylvieCorbet, “SouthernEULeaders Urge Turkey to End “Unilateral'Actions,"(The Washington Post, 10 Eylül2020)<https://www. washingtonpost.com/world/national-security/macron-urges-tough-eu-stance-against-turkish-provocations/2020/09/10/5a53f3dcf356-11ea-8025-5d3489768ac8_story.html> Erişim tarihi 1 Şubat 2021.

59 European Council, "Statement of the Members of the European Council," SN 18/21, 25 March 2021, 5-6.
} 
AB, Doğu Akdeniz'in altında yattığına inanılan enerji kaynaklarının paylaşım mücadelesinde yaşanan uzlaşmazlıklarda 2010'dan itibaren özellikle üye devletler GKRY ve Yunanistan’a olan desteğini açıktan ifade etmektedir. Türkiye'nin Doğu Akdeniz'de en uzun kıyı şeridine sahip olan ülke olmasına karşın bölgedeki faaliyet alanının Antalya Körfezi gibi oldukça dar bir alanla sınırlandırılmaya çalışılmasına yönelik itirazlarının 2003'ten bu yana yeterince dikkate alınmaması, fiili olarak harekete geçmesiyle neticelenmiş ve bugün gelinen noktada Fransa, Yunanistan ve GKRY'nin güncel tutumu nedeniyle Türkiye'nin, $\mathrm{AB}$ ve dünya nezdinde, dayatmacı politikalar izleyen ve uzlaşmaya yanaşmayan bir ülke olarak konumlandırılması ${ }^{60}$ Türkiye'nin kendini yalnız hissetmesine ve AB ile olan ilişkilerini koparma noktasına getirmiştir. Nitekim AB Genel İşler Konseyi, Haziran 2019'da, Türkiye'nin AB'den giderek daha fazla uzaklaştığı yönündeki Haziran 2018 tarihli Konsey tutumunu yinelemiştir. $\mathrm{Bu}$ nedenle, Türkiye'nin katılım müzakereleri fiilen durma noktasına gelmiştir ve yeni fasılların açılması veya kapatılması öngörülmemektedir.

AB Zirvesi 1 Ekim 2020 tarihinde, Türkiye'nin uluslararası hukukun ihlaliyle yeniden tek taraflı eylem veya tahriklerde bulunulması hâlinde kendi çıkarlarını ve üye devletlerin çıkarlarını savunmak amacıyla, AB Antlaşması'nın 29. maddesi ile AB'nin İşleyişi Hakkında Antlaşma'nın 215. maddesi ${ }^{61}$ kapsamındakiler de dâhil olmak üzere, AB'nin tasarrufunda bulunan tüm araçları ve seçenekleri kullanacağını vurgulamıştır.

2020 tarihli Avrupa Komisyonu Türkiye raporunda "Türkiye ve AB arasındaki diyalog, Türkiye'nin Doğu Akdeniz'deki tahrik edici eylemleri ve AB'nin buna ilişkin tepkisi nedeniyle aksamıştır. Türkiye'nin Doğu Akdeniz'de ruhsatsız olarak yürüttüğü sondaj faaliyetleri çerçevesinde, Temmuz 2019'da Konsey; Türkiye ile yürütülen Kapsamlı Hava Taşımacılığı Antlaşması müzakerelerini durdurmaya; Türkiye-AB Ortaklık Konseyi’nin yanı sıra diğer Türkiye-AB Yüksek Düzeyli Diyalog toplantılarını bir süreliğine askıya almaya; Komisyonun 2020 yılı için Türkiye'ye yönelik katılım öncesi yardımın azaltılması önerisini desteklemeye ve Avrupa Yatırım Bankasına, başta devlet destekli olmak üzere Türkiye’ye borç verme faaliyetlerini gözden geçirme çağrısında bulunmaya karar vermiştir" "62 denilerek mevcut AB-Türkiye ilişkileri özetlenmiştir. Raporda ayrıca, Türkiye’nin dış

\footnotetext{
60 İsmail Ermağan ve Aybars Karcı, “Avrupa Birliği’nin Yumuşak Güç Uygulamaları”, in Dr. Ayhan Nuri Yılmaz ve Dr. Gökmen Kılıçoğlu (eds), Yumuşak Güç ve Kamu Diplomasisi Üzerine Akademik Analizler, (Nobel Yayıncılık, 2018) 411-437.

${ }^{61}$ Avrupa Birliği'nin İşleyişi Hakkında Antlaşma, Madde 215: “1. Konsey, Avrupa Birliği Antlaşması’nın V. Başlığının 2. Bölümü uyarınca alınan bir kararın, bir veya birden çok üçüncü ülke ile, ekonomik ve mali ilişkilerin kısmen ya da tamamen kesilmesini veya azaltılmasını öngörmesi hâlinde, Birlik Dışişleri ve Güvenlik Politikası Yüksek Temsilcisi ile Komisyon'un ortak önerisi üzerine, nitelikli çoğunlukla gerekli tedbirleri kabul eder. Konsey, alınan tedbirler hakkinda Avrupa Parlamentosu'nu bilgilendirir.

2. Konsey, Avrupa Birliği Antlaşması'nın V. Başlı̆̆ının 2. Bölümü uyarınca kabul edilen bir kararda öngörülmesi hâlinde, 1 . paragrafta belirtilen usule uygun olarak, gerçek veya tüzel kişilere ve gruplara veya devlet dışı birimlere yönelik kısıtlayıcı tedbirler kabul edebilir."

62 Avrupa Komisyonu Türkiye Raporu $(2020)<$ https://www.ab.gov.tr/siteimages/trkiye_raporustrateji_belgesi_2020/turkey_ report_30.10.2020.pdf> Erişim tarihi 15.01.2021.
} 
politikasının, AB’nin Ortak Dış ve Güvenlik Politikası kapsamındaki öncelikleri ile gittikçe daha fazla çatıştığı ifade edilmiştir. Bu raporda Türkiye ile AB ilişkilerini kopma noktasına getiren en önemli olayın Doğu Akdeniz'de yaşanan gelişmeler olarak dile getirildiği görülmektedir. Sonuç olarak, Türkiye'nin AB ile müzakere süreci hemen hemen durma noktasına gelmiştir.

\section{Doğu Akdeniz’de Deniz Yetki Alanlarının Sınırlandırılması Meselesinin Hukuki Boyutu}

Uluslararası deniz hukukunda pek çok deniz yetki alanından söz edilmekle ve burada kıyı devletinin kullanabileceği hak ve yetkilerin sınırları çizilmekle birlikte, deniz yetki alanlarının sınırlarının çizilmesi kıyıları karşılıklı ve birbirine yakın olan devletler ya da kıyıları yan yana olan devletler söz konusu olduğunda her zaman kolay olmamaktadır. Doğu Akdeniz meselesi özelinde ise KKTC'nin statüsü ve Yunanistan'ın adalar konusundaki tezleri ile GKRY'nin kendini Kıbris Adası'nın tek temsilcisi kabul eden tutumu nedeniyle bu karmaşık deniz hukuku meselelerinin yanına siyasi sorunlar da eklenmektedir.

Doğu Akdeniz'deki sorunlar kıta sahanlığı ve MEB kavramları üzerinde düğümlendiğinden, burada kıta sahanlığı ve MEB alanlarının sınırlandırılması meselesi üzerinde duracağız.

Genel itibariyle uluslararası deniz hukukunda deniz yetki alanlarının belirlenmesinde ana çözüm olarak uyuşmazlık tarafı devletlerin anlaşması esası benimsenmiştir. 1958 Kıta Sahanlığı Sözleşmesi 6. maddesine göre, kıyıları karşılıklı ve bitişik devletlerin kıta sahanlı̆̆ anlaşma yoluyla belirlenecektir. Anlaşma yoksa ve özel şartlar başka bir sınır hattını esas kılmıyorsa, sınırlandırma eşit uzaklık ilkesine göre yapılacaktır. ${ }^{63}$ Maddenin lafzından açıkça anlaşıldığı üzere, taraflar arasında anlaşma bulunmadığı takdirde, eşit uzaklık ilkesinin uygulanabilir olması için özel durumların başka bir sınır çizilmesini gerektirmemesi esastır. Çünkü özel durumların varlığı hâlinde eşit uzaklık ilkesinin uygulanması hakkaniyete aykırı sonuçlar doğurabilir.

Nitekim Kuzey Denizi Kıta Sahanlığı Davası'nda, Danimarka ve Hollanda, 1958 Kita Sahanlığı Sözleşmesi’nin tarafı olmayan Almanya’ya karşı eşit uzaklık ilkesinin bir teamül hukuku kuralı olduğunu ve somut uyuşmazlıkta kıta sahanlığının sınırlandırılmasında uygulanması gerektiğini öne sürmüşlerdir. Ancak ilkenin uygulanması Almanya kıyılarının özel şekli nedeniyle hakkaniyete aykırı sonuçlar doğurmakta ve Almanya'ya oldukça dar bir kıta sahanlığı bırakmaktaydı. BM Uluslararası Adalet Divanı (Divan) sözleşmenin 6. maddesinde yer alan eşit uzaklık ilkesinin teamül hukuku kuralı olmadığına ve kıta sahanlığı sınırlandırmasının

1958 Kita Sahanlığı Sözleşmesi, United Nations, Treaty Series, vol. 499, 311. 
özel durumları da dikkate alan hakça ilkeler çerçevesinde yapılması gerektiğine hükmetmiştir. ${ }^{64}$

1982 Deniz Hukuku Sözleşmesi'nin MEB'e ilişkin 74. maddesi6 ${ }^{65}$ ile kıta sahanlığına ilişkin 83. maddesinde ${ }^{66}$ sınırlandırmaların "hakkaniyete uygun bir çözüme ulaşmak amacıyla" ve "uluslararası hukuka uygun olarak anlaşma ile" yapılacağı öngörülmüştür. Kısacası, 1982 Deniz Hukuku Sözleşmesi uyarınca sınırlandırmada asıl amaç hakça bir çözüme ulaşmaktır. ${ }^{67}$ Ancak her iki maddede de hakça çözüme nasıl ulaşılacağı ve bu minvalde hakça ilkelerin hangileri olduğu konularında yol gösterici bir düzenlemeye yer verilmemiştir. Bu nedenle hakça ilkelerin hangileri olduğunun belirlenebilmesi için içtihada bakmak gerekmektedir. Bu konudaki içtihat ise zaman içerisinde değişikliklere uğramıştır.

Kuzey Denizi Kıta Sahanlığı davasında benimsenen yaklaşım "hakça ilkeler/özel durumlar" prensibi olarak özetlenebilir. İşte başlangıçtaki eğilim, "hakça çözüme ulaşma" nihai amacı çerçevesinde, somut uyuşmazlığın özelliklerine göre değiş̧en ve pek az öngörülebilirliğe sahip çeşitli kriterlerin uygulanmasıdır. ${ }^{68} \mathrm{Bu}$, oldukça esnek yaklaşımın karşısında ise sınırları daha belirli olan ve formüle edilmiş "eşit uzaklık/ özel durumlar" yaklaşımı bulunmaktadır. ${ }^{69}$

Hakça ilkeler uygulamasından, her duruma uygulanabilir ya da belirli durumlara kesin olarak uygulanabilir nitelikte bir hakça ilkeler kataloğu tespit edilememektedir. $\mathrm{Bu}$ nedenle deniz yetki alanlarının sınılandırılmasının, hukuk kuralları ile düzenlenmekten ziyade mahkemelerin takdirine bırakıldığı eleştirisi yapılmıştır. ${ }^{70}$

Gerçekten de Divan hakça ilkelerin belli başlı yol gösterici ilkeler içermesi dışında, teknik ve somut sınırlandırma yöntemlerini ifade etmediğini Maine Körfezi davasına ilişkin kararında şu şekilde kaydetmiştir: "Uluslararası teamül hukuku, temel olarak,

64 Kuzey Denizi Kıta Sahanlığı Davası, Judgment, I.C.J. Reports 1969, 3, para 101 (c) (1).

${ }^{65}$ 'Birleşmiş Milletler Deniz Hukuku Sözleşmesi' (1982) < https://denizmevzuat.uab.gov.tr/uploads/pages/ uluslararasisozlesmeler/denizhukuku.pdf>, Erişim Tarihi 24 Aralık 2020.

Madde 74 Sahilleri bitişik veya karşs karşıya bulunan devletler arasında münhasır ekonomik bölgenin sinırlandırlması

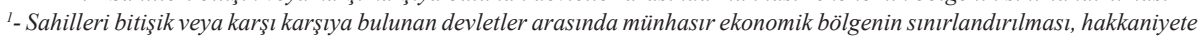
uygun bir çözüme ulaşmak amacıyle, Uluslararası Adalet Divanı Statüsünün 38. maddesinde belirtildiği şekilde uluslararası hukuka uygun olarak anlaşma ile yapılacaktır.

${ }^{66}$ Madde 83 Sahilleri bitişik veya karşı karşıya bulunan devletler arasında kıt'a sahanlığının sınırlandırılması

I- Sahilleri bitişik veya karşı karşıya bulunan devletler arasında kıt'a sahanlığının sınırlandırılması, hakkaniyete uygun bir çözüme ulaşmak amacıyle, Uluslararası Adalet Divanı Statüsü'nün 38. maddesinde belirtildiği şekilde, uluslararası hukuka uygun olarak anlaşma ile yapılacaktır.

67 Yusuf Aksar, Teoride ve Uygulamada Uluslararası Hukuk II (Seçkin Yayıncılık 2013) 59.

${ }_{68}$ Bu eğilimi temsil eden davalar için bkz. Tunus-Libya Kıta Sahanlığı Davası, Continental Shelf (Tunisia/Libyan Arab Jamahiriya), Judgment, I.C.J. Reports 1982, 18; Libya-Malta Kita Sahanlığı Davası, Continental Shelf (Libyan Arab Jamahiriya/Malta), Judgment, I. C.J. Reports 1985, 13; Maine Körfezi Davas1, Delimitation of the Maritime Boundary in the Gulf of Maine Area, Judgment, I. C.J. Reports 1984, 246.

69 Malcolm D. Evans, International Law (Oxford University Press 2003) 648.

70 Yusuf Aksar, 'Is Delimitation of the Continental Shelf and the Exclusive Economic Zone by Arbitrators or the ICJ Really Governed by Legal Rules, or Should It More Accurately Be Seen as a Matter of Arbitrator s (or Judge's) Discretion?' in Abuzer Kendigelen (eds), Prof. Dr. Hayri Domaniç’e 80. Yaş Günü Armağanı Cilt: II (Beta Yayıncılık 2001) 1113. 
amaca ulaşmak için izlenmesi gereken belirli kllavuz ilkeler koyar. Bunun ötesinde, uluslararası hukukun doğrudan sınırlandırma uyuşmazlıklarında uygulanacak teknik ve uygulanabilir yöntemler ile kriterler belirlemesi beklenemez." ${ }^{11}$

İçtihada bakıldığında hakça ilkelerin sınırlı sayıda olmadığı, her somut davanın özelliğine göre uygulanıp uygulanmayacağının değişeceği anlaşılmaktadır. Hakça ilkelere örnek olarak "coğrafyanın yeniden şekillendirilmemesi, "adaların ilgili koşul olarak dikkate alınması", "kara denize hâkimdir", "çakışan deniz yetki alanları taraflardan birinin tek taraflı iradesiyle belirlenemez", "coğrafyanın üstünlüğü” gibi ilkelerden söz edilmektedir. ${ }^{72}$ Ancak bu ilkelerin uygulanması somut olaya göre değiş̧ebildiğinden, farklı yargısal kararlara tanıklık edilmiştir. Örneğin, İngiltere'ye ait Kanal adalarına, çevrelenmiş alan (enclave) yöntemi kullanılarak kuzey ve batı yönünde 12 millik deniz yetki alanı tanınırken, Tunus'a ait Kerkennah adalarına ilişkin sınırlandırmada adalara yarım etki verilmesi söz konusu olmuş, Kanada ile Fransa arasındaki bir tahkim davasında ise Fransa'ya ait adalara verilen deniz yetki alanını güneydoğu istikametinde ince bir şerit olarak belirleyerek doğanın yeniden şekillendirilmesi önlenmeye çalış1mıştır. ${ }^{73}$

Divan, Maine Körfezi davasında hakça ilkeler çerçevesinde sınırlandırmada kullanılan ilkelere örnek olarak: komşu devletler arasındaki sınırlandırmada, özel koşullar bulunmadığı sürece kesişen deniz yetki alanlarının eşit olarak paylaştırılması, her bir devlete mümkün olduğu müddetçe kıyısına yakın deniz yetki alanları verilerek kıyının deniz uzantısının diğer devlet tarafından kapatılmasının önlenmesi, devletlerin kıyılarının ötesindeki deniz projeksiyonunun mümkün olduğunca diğer devlet tarafından kesilmesinin önlenmesi, aynı sınırlandırma bölgesinde bulunan ancak farklı kıyı uzunluğuna sahip devletler arasındaki sınırlandırmanın bu koşullara uygun gerçekleştirilmesini saymıştır. ${ }^{74}$

1993 'te Danimarka ile Norveç arasındaki Jan Mayen davasında ise Divan, prima facie, kıyıları karşılıklı devletler arasındaki sınırlandırmada orta hat/eşit uzaklık yönteminin genel olarak hakça çözümü sağlayacağını ifade etmiştir. ${ }^{75}$ Divan, Katar ile Bahreyn arasındaki davada ise eşit uzaklık ilkesi uygulanarak sınırlandırmaya başlanacağını, daha sonra hakça çözüme ulaşmak için bu hat üzerinde gerekli değiş̧ikliklerin yapılacağını öngörmüştür. ${ }^{76}$ Kamerun ile Nijerya arasındaki davada

\footnotetext{
Maine Körfezi Davas1, para. 81.

72 Yunus Emre Açıkgönül, Deniz Yetki Alanlarının Hakça İlkeler Çerçevesinde Sinırlandırılması (Legal Yayıncılık 2012) 48, 52.

73 ibid 52-53.

${ }^{74}$ Maine Körfezi Davas1, para 157.

75 Jan Mayen Davas1, Maritime Delimitation in the Area between Greenland and Jan Mayen, Judgment, I.C.J. Reports 1993,38, para. 64

76 Katar/Bahreyn Davas1, Maritime Delimitation and Territorial Questions between Qatar and Bahrain, Merits, Judgment, I. C. J. Reports 2001, 40, para. 230.
} 
da aynı uygulama devam ettirilmiştir. ${ }^{77}$ Buna göre bir orta hat çizildikten sonra, hakça bir sonuca ulaşmak için bu hattın ayarlanmasını veya kaydırılmasını gerektiren faktörlerin bulunup bulunmadığı dikkate alınmalıdır. ${ }^{78}$ Böylelikle "eşit uzaklık/özel durumlar" prensibinin benimsenmeye başlandığı anlaşılmaktadır.

Barbados ile Trinidad Tobago arasındaki tahkim davasında verilen 2006 tarihli kararda, hakça mülahazalar, yargı sürecinden beklenen belirlilik ve kesinlik gereği karşısında başlı başına belirsiz bir kavram olarak nitelendirilmiş ve sınırlandırma için öngörülebilir ve objektif olarak tespit edilebilir kriterlere duyulan ihtiyaç nedeniyle hakkaniyetin hukukun ötesinde değil hukuk sınırları içinde bir anlam taşıdığı vurgulanmıştır. ${ }^{79}$

Divan, Romanya ve Ukrayna arasında gördüğü davada üç aşamalı testten söz etmiş ${ }^{80}$, Peru ile Şili arasında görülen davada da yine üç aşamalı testi uygulayarak bu yaklaşımını sürdürmüştür. Peru-Şili davasında verdiği kararda Divan, 1982 Deniz Hukuku Sözleşmesi'nin 74(1) ve 83(1) maddelerinin teamül hukuku kuralları olduğuna hükmetmiştir. Üç aşamalı teste göre ise, ilk olarak (aksini gerektiren sebepler bulunmadığı müddetçe) geçici bir orta hat çizilecektir. İkinci olarak hakça bir çözüme ulaşmak için bu hattın uyarlanmasını gerektiren ilgili durumların var olup olmadığı değerlendirilecektir. Üçüncü aşamada ise orantısızlık testi uygulanacak, uyarlanmış hattın etkisi değerlendirilerek tarafların ilgili deniz yetki alanındaki paylarının kıyılarının uzunluğuna göre önemli derecede orantısız olup olmadı̆̆ tespit edilecektir. ${ }^{81}$

Eşit uzaklık ilkesi sınırlandırmada başlangıç noktası olarak esas alındıktan sonra, özel durumlar çerçevesinde gerekli değişikliklerin yapılması uygulaması her ne kadar, hakça ilkelere vurgu yapan ilk dönem yaklaşımına nazaran daha öngörülebilir nitelikte olsa da; özel durum olarak dikkate alınabilecek faktörler sınırlı sayıda değildir. Ancak uygulamada dikkate alınmakta olan ve öne çıkan belirli faktörlerden söz edilebilir. Örneğin, devlete ait deniz yetki alanlarının kıyılarının uzunluğuna kıyasla orantısız olmaması (orantıllık ilkesi) ve adaların varlığı mahkemeler ve hakemlikler tarafindan sınırlandırmada dikkate alınan faktörler iken, kıyılar arasındaki uzaklığın 400 milden

\footnotetext{
7 Kamerun/Nijerya Davası, Land and Maritime Boundary between Cameroon and Nigeria (Cameroon v. Nigeria: Equatorial Guinea intervening), Judgment, I. C. J. Reports 2002, 303, para. 288.

78 ibid 441.

79 Barbados/Trinidad Tobago Davas1, Arbitration between Barbados and the Republic of Trinidad and Tobago, relating to the delimitation of the exclusive economic zone and the continental shelf between them, decision of 11 April 2006 United Nations Reports of International Arbitral Awards Vol XXVII 147-251, para. 230

${ }^{80}$ Romanya/Ukrayna Davası, Maritime Delimitation in the Black Sea (Romania v. Ukraine), Judgment, I.C.J. Reports 2009, 61.

81 Peru/Şili Davası, Maritime Dispute (Peru v. Chile), Judgment, I.C.J. Reports 2014, 3, 65. Bu yaklaşım şu davalarda da benimsenmiştir: Guyana/Surinam Davası, Award in the arbitration regarding the delimitation of the maritime boundary between Guyana and Suriname, Award of 17 September 2007 United Nations Reports of International Arbitral Awards Vol XXX para. 340-341; Bangladeş/Hindistan Davası, 'Award of 7 July 2014' $<$ https://pcacases.com/web/sendAttach/383> Erişim tarihi 24 Aralık 2020 para. 340.
} 
az olduğu durumlarda jeolojik faktörler dikkate alınmamakta ${ }^{82}$ ve ekonomik faktörler ise genel itibariyle ilgili görülmemektedir. ${ }^{83}$

Shaw, geçici orta hat çizildikten sonra yapılacak uyarlama açısından içtihat hukukuna göre şu kriterlerin dikkate alınacağını kaydetmektedir ${ }^{84}$ : İlk olarak, sınırlandırmada, bir tarafın diğerinin doğal uzantısını kapatmasından kaçınılmalı ve mümkün olduğunca ilgili kıyı çizgilerinin deniz projeksiyonunun bölünmemesine çalışılmalıdır. ${ }^{85}$ İkinci olarak, kıyının şekli ilgili bir faktör olabilir (özellikle orta hat çizilirken bir devletin içbükey veya dişbükey şeklinde olan kıyısı komşularına nazaran o devletin önemli derecede zararına yol açıyorsa) ${ }^{86}$ Üçüncüsü tarafların ilgili kıyı çizgilerinin uzunlukları arasındaki önemli ölçüde farklılık, orta hattın uyarlanmasında dikkate alınacak bir faktör olabilir. ${ }^{87}$ Dördüncüsü, adaların veya diğer benzeri unsurların varlığı, geçici orta hattın uyarlanmasını haklı kılabilir. ${ }^{88}$ Beşincisi, güvenlikle ilgili mülahazalar dikkate alınabilir, ancak bunun etkisinin tam olarak ne olduğu belirsizdir.

Öyleyse güncel yargısal uygulamalar Türkiye ile Yunanistan arasında olabilecek olası bir sınırlandırmada, öncelikle geçici bir orta hat çizilebileceği ve bu hattın ilgili faktörler uyarınca uyarlanabileceğini göstermektedir. Somut durum özelinde hangi faktörlerin dikkate alınabileceği incelendiğinde özellikle "orantılılık ilkesi" ve "kapatmama ilkesi" ve adaların sınırlandırmada dikkate alınması ön plana çıkmaktadır.

\section{A. Orantılılık ilkesi}

Devlete ait deniz yetki alanlarının devletin kıyılarının uzunluğuna kıyasla orantısız olmaması, Doğu Akdeniz uyuşmazlığı ve Türkiye'nin tezleri açısından oldukça önemlidir. Belirtildiği üzere GKRY'nin ilan ettiği MEB çerçevesinde bazı ruhsat sahaları, Türkiye'nin ilan ettiği kıta sahanlığı ile çakışmaktadır. Bunun yanı sıra Türkiye ile Libya arasında akdedilen antlaşma sonrasında çakışan alanlara Yunanistan'ın iddia ettiği MEB alanı da eklenmiştir. Dolayısıyla özellikle GKRY'nin bir ada olması ve Türkiye'nin GKRY'ye kıyasla Akdeniz'e olan ilgili kıyı uzunluğu göz önüne alındığında, Kıbrıs ${ }^{89}$ ile yapılacak olası bir sınırlandırmada orantılılık ilkesi çerçevesinde yapılacak bir uyarlama hakça çözüme ulaşmak bakımından bir

\footnotetext{
2 Libya/Malta Kıta Sahanlığı Davası, para. 39.

83 Evans (n 69) 649.

${ }^{84}$ Malcolm N. Shaw, International Law (Cambridge University Press 2017) 451.

85 Barbados/Trinidad Tobago Davas1, para. 232.

86 Kamerun/Nijerya Davası, 445-446.

87 Örneğin bkz. Kamerun/Nijerya Davası, 446-447, Barbados/Trinidad Tobago Davası, 240. Ayrıca bkz. Peru/Şili Davası, 65.

88 Örneğin bkz. İngiltere/Fransa Kita Sahanlığı Davası, Delimitation of the Continental Shelf between the United Kingdom of Great Britain and Northern Ireland, and the French Republic (UK, France), International Law Reports, Vol. 54, 6, Katar/ Bahreyn Davas1, para. 114.

89 Gelecekte Kıbrıs adası ile, olası bir siyasi bir çözüm akabinde yapılacak sınırlandırma kastedilmektedir.
} 
zaruret teşkil edecektir. ${ }^{90}$ Türkiye'nin deniz yetki alanlarının belirlenmesi ile ilgili olan kıyı uzunluğu Antalya Gazipaşa-Muğla Deveboynu arasında olup 656 mil iken, GKRY'nin Kıbrıs adasının batısındaki kıyı hattı 32 mildir. ${ }^{91}$ Dolayısıyla sahip olacakları deniz yetki alanları da bu uzunluklar ile orantılı olmalıdır. GKRY ise sırasıyla Mısır, Lübnan ve İsrail ile akdettiği deniz yetki alanlarının sınırlandırılması anlaşmalarında eşit uzaklık ilkesini uygulamış ve Türkiye'nin güney kıyıları önünde yer alan bir ada olarak kendisine tam deniz yetki alanı (200 mil uzunluğunda MEB) tanımıştır.

Diğer yandan Yunanistan adaların tam deniz yetki alanlarına sahip olması gerektiğini öne sürerek, Mısır ile akdettiği deniz yetki alanları sınırlandırılması anlaşmasında adalara tam etki tanımış ise de, Türkiye orantılılık ilkesi nedeniyle buna karşı çıkmaktadır. Türkiye BM daimi temsilcisinin BM Genel Sekreterliğine mektubunda Libya ile akdedilen mutabakat muhtırasının orantılılık ilkesine dayandığ 1 şu şekilde ifade edilmiş̧ir: "Klyıların uzunluğu ve istikameti deniz yetki alanları sinırlandirllırken dikkate alınmalıdır."

\section{B. Kapatmama ilkesi}

Sınırlandırmada, bir tarafın diğerinin doğal uzantısını kapatmasından kaçınılması ve mümkün olduğunca ilgili kıyı çizgilerinin deniz projeksiyonunun bölünmemesine yukarıda önemli ilkelerden biri olarak yer verilmiştir. Örneğin Kuzey Denizi Kıta Sahanlığı davasında Divan; her bir devletin kıta sahanlığının, o devletin kara ülkesinin uzantısı olduğunu ve başka bir devletin ülkesinin doğal uzantısını bölmemesi gerektiğini ifade etmiştir. ${ }^{93}$ Benzer biçimde Maine Körfezi davasında Divan, "mümkün olduğu takdirde bir devletin kıyısının denize uzantısının, başka bir devletin kıyılarına çok yakın alanları kapatmaması kriteri”ne ve "mümkün olduğunca kıyının denize projeksiyonunun kesilmesinin önlenmesi kriteri"ne yer vermiş̧iri. ${ }^{94}$ Barbados/Trinidad Tobago davasında ise hakem mahkemesi mümkün olduğunca sınırlandırmadan kaynaklanan kesme etkisinin olmamasına dikkat ettiğini ve aynı zamanda uyarlanmamış bir orta hat çizgisi nedeniyle oluşabilecek kapatmanın da önlenmesine dikkat ettiğini kaydetmiştir. ${ }^{95}$

Doğu Akdeniz'deki uyuşmazlık büyük ölçüde adaların deniz yetki alanlarına ilişkin tartışmalardan kaynaklandığından, adaların deniz yetki alanlarının belirlenmesinde kapatmama ilkesinin dikkate alınması bakımından Fransa-Kanada arasında görülen

\footnotetext{
90 Sertaç Hami Başeren, 'Doğu Akdeniz Deniz Yetki Alanları Uyuşmazlığı' (2010) 8(14) Stratejik Araştırmalar Dergisi 129, 167

91 Açıkgönül (n 72) 87, dn 182.

92 Letter dated 18 March 2020 (n 41)

93 Kuzey Denizi Kıta Sahanlığı Davası, para 85.

94 Maine Körfezi Davası, para 157. Aynı yönde bkz. Libya/Malta Kıta Sahanlığı Davası, para 46.

95 Barbados/Trinidad Tobago Davası, para 375.
} 
dava önemlidir. Mahkeme bu davada Fransa'ya ait Saint Pierre ve Miquelon adalarının güney yönünde sahip olacağı deniz yetki alanlarının genişliğini belirlemiştir. Mahkeme bu adalara Kanada'nın denize olan projeksiyonu üzerinde kapatma etkisi yaratmadığından $^{96}$ güney yönünde 200 millik deniz yetki alanı tanımıştır.

GKRY ve Yunanistan ise, başta Rodos, Meis ve Kıbrıs olmak üzere adaların coğrafi konumlarını kullanarak, tek taraflı uygulamalar ve diğer sahildar devletlerle yaptıkları ikili anlaşmalarla Türkiye'yi Doğu Akdeniz'de Antalya Körfezi açıklarında dar bir deniz alanına hapsetme çabasındadır. ${ }^{97} \mathrm{Bu}$ maksatla Anadolu ile bu adalar arasındaki orta hatları, sırasıyla Türkiye-Yunanistan ve Türkiye-Kıbrıs deniz yetki alanları sınırı hâline dönüştürmeye çalışmaktadırlar. ${ }^{98}$ Söz konusu sınırların Türkiye'nin kıyılarının denize projeksiyonunu kesmeyecek bir hâle getirilmesi hakça ilkelerin gereğidir. ${ }^{99}$

Türkiye BM daimi temsilcisinin BM Genel Sekreterliğine mektubunda Libya ile akdedilen mutabakat muhtırasının kapatmama ilkesine dayandığ 1 şu şekilde ifade edilmiştir: “Adalar Doğu Akdeniz'de en uzun kıyı çizgisine sahip olan Türkiye’nin kıyı projeksiyonu üzerinde kesme etkisine sahip olamaz." 100

\section{Adaların Durumu}

Doğu Akdeniz'de deniz yetki alanlarının paylaşılmasına ilişkin sorunun en önemli boyutu adalara tanınacak etkiye ilişkindir. Yunanistan, yapılacak karşılıklı deniz yetki alanlarının sınırlandırılması işleminde Girit ve Rodos gibi Doğu Akdeniz’e kıyısı bulunan adalarının esas alınması gerektiği tezini benimsemiştir. Buna göre çizilecek orta hat Yunanistan ana karasından itibaren değil, söz konusu adalardan itibaren ölçülmelidir. Yunanistan ile Mısır arasında akdedilen deniz yetki alanları anlaşmasında da Misır ile çizilen (Yunanistan lehine kaydırılmış) orta hatta, adalar esas alınmıştır. Türkiye ise Yunanistan ile Ege Denizi'ndeki deniz yetki alanları uyuşmazlığında benimsediği tavrı tutarlı biçimde sürdürerek, çizilecek orta hattın Yunanistan anakarası kıyıları ile Anadolu kıyıları esas alınarak tespit edilmesi gerektiğini savunmaktadır. Buna gösterilen gerekçelerden birinin adaların Türkiye'nin kıyı projeksiyonunu kesmemesi, yani kapatmama ilkesi olduğu yukarıda belirtilmişti. Bunun yanı sıra adalara ilişkin olarak "iki anakara arasında çizilen orta hattın ters tarafinda kalan adalar karasularının ötesinde deniz yetki alanlarına sahip

\footnotetext{
96 Fransa/Kanada Davas1, Court of Arbitration for the Delimitation of Maritime Areas between Canada and France: Decision in Case concerning Delimitation of Maritime Areas(St. Pierre and Miquelon), 1992 International Legal Materials 31(5) 1145 , para 70 .

${ }_{97}$ Sami Doğru, 'Doğu Akdeniz'de Hidrokarbon Kaynakları ve Uluslararası Hukuka Göre Bölgedeki Kıta Sahanlığı ve Münhasır Ekonomik Bölge Alanlarının Sınırlandırılması' (2015) 119 Türkiye Barolar Birliği Dergisi 503, 513.

98 ibid

99 Yaycı, Türkiye ana karası ile komşu ana karalar arasında çizilecek "orta hattın” kuzeyinde kalan Kıbrıs Adası ile Yunan adalarının ters tarafta bulunmaları ve Anadolu sahillerinin önünü kapatmak suretiyle Türkiye'nin denize açılımını engelleyecek coğrafi bir konumda olmaları nedeniyle, sadece karasuları kadar deniz yetki alanlarına sahip olmalarının hakça çözüm olduğunu belirtmektedir. Bkz.Yayc1, (n 1) 39, dn 102.

100 Letter dated 18 March 2020 (n 41)
} 
olamaz." ifadesi ile Türkiye söz konusu uyuşmazlık hakkındaki temel tezlerinden birini ortaya koymuştur. ${ }^{101}$

1982 Deniz Hukuku Sözleşmesi 121. maddesine göre adaların rejimi şu şekilde düzenlenmiştir: "1-Bir ada, sularla çevrili olan ve sular yükseldiğinde su üstünde kalan, doğal olarak meydana gelmiş bir kara parçasıdır. 2- 3. paragraf hükümleri saklı kalmak üzere, bir adanın karasularının, bitişik bölgesinin, münhasır ekonomik bölgesinin ve kıta sahanlığının sınırlandırılması, işbu Sözleşmenin diğer kara parçalarına uygulanabilir hükümlerine uygun olarak yapılır. 3- Insanların oturmasına elverişli olmayan veya kendilerine özgü ekonomik bir yaşamı bulunmayan kayalıkların münhasır ekonomik bölgeleri veya kıta sahanlıkları olmayacaktır." Görüldüğü üzere adaların deniz yetki alanlarına sahip olabilmesi, hakça çözüm uyarınca sinırlandırmaya tâbi olmaktan muaf oldukları anlamına gelmemektedir. 1982 Deniz Hukuku Sözleşmesi 2. fikrada açıkça adaların sahip olacağı deniz yetki alanlarının kara parçalarının tâbi olduğu sınırlandırma kurallarına tâbi olacağını düzenlemiştir. İçtihat hukukuna göre ayrıca adaların varlığg, deniz yetki alanlarının sinırlandırılmasında dikkate alınan faktörlerden biridir.

Genel olarak, adalar ve ana kıta ile adalar arasındaki sınırlandırmaya ilişkin uygulamada, adalara tam etki veren, yarım ya da kısmi etki veren, hiç etki vermeyen ve çevrelenmiş alan (enclave) metodunun uygulandığı örnekler bulunmaktadır. ${ }^{102}$ $\mathrm{Bu}$ noktada önemli olan adaların kıyıya göre olan coğrafi konumudur. Dolayısıyla sınırlandırmada adalara verilecek etkinin belirlenmesi amacıyla coğrafi açıdan şöyle bir sinıflandırma yapılmaktadır: Klyıya yakın adalar (offshore islands), kıyıya uzak ama ortay hattın berisindeki adalar (off lying islands/detached islands), ortay hat bölgesindeki adalar (islands in the median zone,) ters taraftaki adalar (islands 'on wrong side) ve ada devletleri. ${ }^{103}$

Adaya tam etki verilmesi, ilgili adaların anakara kıyısının ayrılmaz bir parçasını oluşturduğu takdirde söz konusudur. ${ }^{104}$ Örneğin Dahlakh adalarına genel kıyı yapısının ayrılmaz bir parçasını oluşturan ada grupları olmaları sebebiyle hakem mahkemesi kararı ile tam etki tanınmıştır. ${ }^{105}$ Benzer biçimde Yemen'e ait, Kamara, Uqban ve Kutama adalarına da tam etki tanınmıştır. ${ }^{106}$

Konu Doğu Akdeniz uyuşmazlığı açısından ele alındığında, yukarıda belirtildiği üzere anlaşmazlığın temelinde Yunanistan'ın en doğudaki Girit, Rodos, Meis, Kerpe 
gibi adalara tam etki tanıması yer almaktadır. Söz konusu adalar coğrafi bakımdan Anadolu kıyılarına yakın olup, Yunan anakarası ile Anadolu arasında çizilecek bir orta hattın ters tarafında kalmaktadırlar. Bu bakımdan açıktır ki söz konusu adalar içtihat hukuku açısından tam etki tanınacak adalardan değildir. $\mathrm{Bu}$ nedenle konunun ters taraftaki adalar açısından incelenmesi gerekmektedir.

Örneğin Sürekli Hakemlik Mahkemesi tarafından görülen Kanal Adaları'na ilişkin İngiltere/Fransa Kıta Sahanlığı davasında İngiltere egemenliği altında bulunan ancak Fransa kıyılarına yakın bulunan Kanal Adaları'na tam etki tanınması, mahkeme tarafından hakkaniyete aykırı bir durum olarak nitelendirilmiştir. ${ }^{107} \mathrm{Bu}$ nedenle mahkeme öncelikle iki devletin anakaraları arasında bir orta hat çizmiş, daha sonra adaları kuzey ve batı yönünde 12 millik çevrelenmiş alan içine almıştır. ${ }^{108} \mathrm{Bu}$ yöntemde mahkeme ilk adımda çizilen sınırı değiştirmeden, ters tarafta kalan adalara, bu daire içinde kalan alanı vermekle yetinmektedir. ${ }^{109}$

Doğu Akdeniz meselesine emsal olması açısından son derece önemli bir karar, Romanya ile Ukrayna arasında görülen Serpents adasına deniz yetki alanı tanınmamasına ilişkin karardır. Bu kararda Divan, Serpents adasına yalnızca 12 millik karasuları tanımış; MEB ve kıta sahanlığı tanımamıştır. Divana göre: "Tek başına anakaradan 20 mil uzaklıkta bulunan Serpents adası, Ukrayna'nın klyı çizgisini oluşturan ada saçağının bir parçası değildir ve Serpents adasını kıyının bir parçası saymak Ukrayna kıyı çizgisine yabancı bir unsurun eklenmesi anlamını taşıyacaktır; ki bu durum yargısal olarak coğrafyanın yeniden şekillendirilmesi anlamina gelir." 110 Söz konusu nedenlerle Romanya ile Ukrayna arasında belirlenecek geçici orta hattın çizilmesinde Serpents adaları dikkate alınmamıştır. Bu noktada, hakça ilkelerden "doğanın/coğrafyanın yeniden şekillendirilmemesi" ilkesinin davada uygulandığının altını çizmek ve ilkenin Türkiye bakımından da önem arz edebileceğini belirtmek isteriz.

Yunan adalarının Doğu Akdeniz'deki durumu ile gösterdiği benzerlik nedeniyle verilen karar Türkiye'nin tezlerinin bir dayanağı açısından önemlidir. Belirtildiği üzere Türkiye'nin Doğu Akdeniz'de Yunan adalarının sahip olacağ 1 alan bakımından temel tezlerinden biri "Ikki anakara arasında çizilen orta hattın ters tarafinda kalan adalar karasularının ötesinde deniz yetki alanlarına sahip olamaz" ilkesi idi. ${ }^{111}$ Romanya/Ukrayna davasında verilen karara göre orta hat çizildiğinde ters tarafta kalan adalar deniz yetki alanı sınırlandırmasında karasularına sahip olurken, bu adalara kıta sahanlığ 1 ve MEB tanınmaması, her

\footnotetext{
107 İngiltere/Fransa Kita Sahanlığı Davası, 93, para 196.

108 ibid., 94-95, para 201-202.

109 Doğru (n 97) 532. Ters tarafta kalan adalara ilişkin devlet uygulamaları için bkz. Doğru (n 96) 533.

110 Romanya/Ukrayna Davası, para 149.

111 Letter dated 18 March 2020 (n 41)
} 
uyuşmazlı̆̆ın özel durumlarının kendi içerisinde değerlendirilmesi koşuluyla, genel kabul görmüştür. ${ }^{12}$

Diğer yandan, uyuşmazlığın bir diğer boyutu GKRY'nin bulunduğu Kıbrıs Adasına ilişkindir. Belirtildiği üzere GKRY akdettiği deniz yetki alanları sınırlandırma anlaşmalarında orta hattı esas alarak kendisine tam etki tanımıştır. Bu bakımdan ada devletinin diğer kıta devleti kıyıları karşısındaki durumuna ilişkin önemli bir dava Libya/ Malta Kıta Sahanlığı davasıdır. Bu davada mahkeme ada devleti olan Malta'ya deniz yetki alanları bakımından tam etki tanımamıştı.. ${ }^{113}$ Bunun nedeni de sınırlandırılacak bölgeye bakan sahiller arasındaki 1:8 oranında Libya lehine olan farklllıktır. ${ }^{114} \mathrm{Bu}$ nedenle, yukarıda, orantılılık ilkesi incelenirken de yer verildiği gibi, Türkiye ile Kıbrıs Adası arasındaki olası bir sınırlandırmada, Kıbrıs'ın sınırlandırma alanı ile ilgili kıyılarının uzunluğunun ve bunun Türkiye kıyılarına oranının dikkate alınması gerekir.

\section{Sonuç}

Deniz yetki alanlarının temelde devletler arasında akdedilecek anlaşmalar ile belirlenmesi prensibi, Doğu Akdeniz'e kıyısı olan devletleri bir anlaşma akdetme yarışına sokmuştur. Ancak tarafları farklı olan bu ikili anlaşmalar Doğu Akdeniz' deki deniz yetki alanlarının birbiri ile çakışması sonucunu doğurmuştur. Divan'ın yukarıda incelediğimiz üzere deniz yetki alanlarının sınırlandırılmasına ilişkin önemli içtihatları bulunmakla birlikte; Divan'ın yargısal yetkisinin ihtiyariliği Türkiye ile Yunanistan'a aralarındaki deniz hukukuna ilişkin sorunların çözümünde yargısal ya da siyasi çözüm yolları arasında bir tercih şansı tanımaktadır. Yargısal çözüm yolunun tercih edilmesi, yukarıda açıklanan ad hoc tahkim içtihatlarının yerleşik olmaması ve hakça ilkelerin uygulanması konusundaki karmaşı ve zaman içinde değişen Divan içtihadı göz önünde bulundurulduğunda riskli bir yol olacaktır. Yargısal çözüm kapsamında uyuşmazlı̆̆ın Divan'ın önüne taşınması ihtimalinde ise, her ne kadar Divan kararlarında önceki içtihatlarına atıf yapsa ve belirli ölçüde tutarlılık gözetse dahi Divan Statüsü’nün 59. maddesi uyarınca önceki içtihadı ile bağlı değildir. Ayrıca karmaşık coğrafi yapıların ve pek çok değişkenin bulunduğu deniz alanlarının sınırlandırılması denkleminde, Divan tarafından verilecek kararın matematiksel bir kesinlikle saptanması bir yana, kaba taslak bir tahminde bulunmak dahi zordur. $\mathrm{Bu}$ nedenle son derece yüksek ekonomik değeri bulunan kaynaklar içeren kıta sahanlığı ve MEB alanlarının saptanmasında yargısal çözüme başvurmak, riskli bir hamle olabilir. Bu bakımdan, siyasi çözüm yolu kapsamında müzakerelerin tercih edilmesinin yargısal kararın kesinliğinden uzak olması ve en azından bir

\footnotetext{
112 Nası Sarp Ergüven, 'Karadeniz'de Deniz Alanı Sınırlandırması Davası (Romanya/Ukrayna) ve Uluslararası Hukuk Açısından Etkileri' (2014) 63(2) Ankara Üniversitesi Hukuk Fakültesi Dergisi, 309, 325. Karar hakkında başka bir detaylı inceleme için bkz. Uğur Bayıllığlu, 'Uluslararası Adalet Divanının Romanya ile Ukrayna Arasındaki Deniz Alanı Sınırlandırmasında Serpents Adasının Etkisine İlişkin Tespitleri’ (2010) 7(1) Cankaya University Journal of Law 23.

113 Libya/Malta Kıta Sahanlığı Davası, para 74-75.

114 Doğru (n 97) 534.
} 
uzlaşma elde edilemediği takdirde masayı terk etme şansı tanıması bakımından yerinde olduğu kanaatindeyiz. Zaten Türkiye'nin 1982 Deniz Hukuku Sözleşmesi’ne taraf olmamasının önemli nedenlerinden biri öngörülen karasuları genişliğinin yanı sıra sözleşmenin zorunlu yargı yetkisine ilişkin düzenlemeleridir. Kısacası Türkiye en başından beri deniz hukukuna ilişkin meselelerin çözümünde uluslararası yargı yoluna mesafeli durmuştur.

Ancak güncel yargısal uygulamalar Türkiye ile Yunanistan arasında olabilecek olası bir sınırlandırmada, öncelikle geçici bir orta hat çizilebileceği ve bu hattın ilgili faktörler uyarınca uyarlanabileceğini göstermektedir. Her ne kadar söz konusu faktörler ve hakça ilkeler sınırlı sayıda olmasa da; özellikle devlete ait deniz yetki alanlarının devletin kıyılarının uzunluğuna kıyasla orantısız olmaması, mümkün olduğunca kıyının denize projeksiyonunun kesilmesinin önlenmesi ilkeleri ve Doğu Akdeniz'de Yunan adalarının sahip olacağı alan bakımından yukarıda incelediğimiz Romanya ile Ukrayna arasındaki Serpents adasına ilişkin kararda temel alınan anakaradan uzakta bulunan adaların karşılıklı kıyısı bulunan devletin kıyı çizgisine yabancı unsur eklenmesi oluşturacak biçimde coğrafyanın yeniden şekillendirilmesi sonucu doğurmaması biçimindeki karar Türkiye'nin tezlerinin uluslararası hukuktaki karşılıklarıdır.

Türkiye ile $\mathrm{AB}$ arasındaki güncel siyasi gelişmeler ise, Türkiye'nin yürüttüğü sondaj faaliyetlerinin $\mathrm{AB}$ tarafından ilişkileri kopma noktasına getiren en önemli sebep olarak değerlendirildiğini göstermektedir. Öyle ki AB'nin tepkisi diyalog toplantılarının askıya alınması, Türkiye'ye katılım öncesi finansal yardımların azaltılması ve Türkiye'ye borç verme faaliyetlerinin gözden geçirilmesi noktasına kadar genişlemiştir. Diğer yandan AB'nin üyeleri Yunanistan ve GKRY'den yana tavir alması ve hatta bu konuda sert bir tutum izlemesi, Yunanistan ve GKRY'nin müzakereler sırasında tavizsiz ve talepkar davranması olasılığını arttırması nedeniyle müzakerelerden bir sonuç elde edilebilmesi ya da istenen sonucun elde edilebilmesi ihtimalini azaltmaktadır. Ancak elbette pek çok dinamiğin etkili olduğu uluslararası siyaset bu konuda nihai belirleyici olacaktır.

\footnotetext{
Hakem Değerlendirmesi: Dış bağımsız.

Çıkar Çatışması: Yazarlar çıkar çatışması bildirmemiştir.

Finansal Destek: Yazarlar bu çalışma için finansal destek almadığını beyan etmiştir.

Yazar Katkısı: Çalışma Konsepti/Tasarımı: T.Y.M., M.A.K, M.İ.A..; Veri Toplama:T.Y.M., M.A.K, M.İ.A.; Veri Analizi / Yorumlama:T.Y.M., M.A.K, M.İ.A.; Yazı Taslağı: T.Y.M., M.A.K, M.İ.A.; İçeriğin Eleştirel İncelemesi: T.Y.M., M.A.K, M.İ.A.; Son Onay ve Sorumluluk: T.Y.M., M.A.K, M.I.A.

Peer-review: Externally peer-reviewed.

Conflict of Interest: The authors have no conflict of interest to declare.

Grant Support: The authors declared that this study has received no financial support.

Authors Contributions: Conception/Design of study:: T.Y.M., M.A.K., M.İ.A..; Data Acquisition:T.Y.M., M.A.K., M.İ.A.; Data analysis/Interpretation:T.Y.M., M.A.K., M.İ.A.; Drafting Manuscript: T.Y.M., M.A.K., M.İ.A.; Critical Revision of Manuscript: T.Y.M., M.A.K., M.İ.A.; Final Approval and Accountability: T.Y.M., M.A.K., M.İ.A.
} 


\section{Bibliyografya / Bibliographie}

1958 Kita Sahanlığı Sözleşmesi, United Nations, Treaty Series, vol. 499, 311.

1982 Birleşmiş Milletler Deniz Hukuku Sözleşmesi, <https://denizmevzuat.uab.gov.tr/uploads/ pages/uluslararasi-sozlesmeler/denizhukuku.pdf>, Erişim Tarihi 24 Aralık 2020

'A Law to Provide for the Proclamation of the Exclusive Economic Zone By Republic of Cyprus' (UN, 2 Nisan 2004) <https://www.un.org/Depts/los/LEGISLATIONANDTREATIES/ PDFFILES/cyp_2004_eez_proclamation.pdf> Erişim tarihi 27 Kasım 2020.

Açıkgönül Y E, Deniz Yetki Alanlarının Hakça İlkeler Çerçevesinde Sınırlandırılması (Legal Yayınc1lık 2012)

'Agreement Between The Republic of Cyprus and the Arab Republic of Egypt on the Delimitation of the Exclusive Economic Zone' (UN, 2003) <https://www.un.org/Depts/los/ LEGISLATIONANDTREATIES/PDFFILES/TREATIES/EGY-CYP2003EZ.pdf> Erişim tarihi 27 Kasim 2020.

'Agreement Between The Government of the State of Israel and the Government of the Republic of Cyprus on the Delimitation of the Exclusive Economic Zone' (UN, 2010) <https://www. un.org/Depts/los/LEGISLATIONANDTREATIES/PDFFILES/TREATIES/cyp_isr_eez_2010. pdf $>$ accessed 27 November 2020.

Aksar Y, 'Is Delimitation of the Continental Shelf and the Exclusive Economic Zone by Arbitrators or the ICJ Really Governed by Legal Rules, or Should It More Accurately Be Seen as a Matter of Arbitrator s (or Judge's) Discretion?' in Abuzer Kendigelen (eds), Prof. Dr. Hayri Domaniç'e 80. Yaş Günü Armağanı Cilt: II (Beta Yayıncılık 2001)

Aksar Y, Teoride ve Uygulamada Uluslararası Hukuk II (Seçkin Yayıncılık 2013)

Aksu, F “Doğu Akdeniz Deniz Yetki Alanları Sorunu ve Türkiye-AB İlişkileri”, in Sertaç Hami Başeren (eds), Doğu Akdeniz’de Hukuk ve Siyaset, (A.Ü. SBF Yay., 2013) 159-196.

Antonopoulos, P 'Cyprus is reopening relations with Syria' (Greek City Times, 2020) <https:// greekcitytimes.com/2020/05/13/cyprus-is-reopening-relations-with-syria> Erişim Tarihi 26 Kasım 2020. Avrupa Birliği Antlaşması, 1992.

Avrupa Komisyonu Türkiye Raporu (2020) <https://www.ab.gov.tr/siteimages/trkiye raporustrateji_belgesi_2020/turkey_report_30.10.2020.pdf $>$ Erişim tarihi 15.01.2021.

Barbados/Trinidad Tobago Davas1, Arbitration between Barbados and the Republic of Trinidad and Tobago, relating to the delimitation of the exclusive economic zone and the continental shelf between them, decision of 11 April 2006 United Nations Reports of International Arbitral Awards Vol XXVII 147-251.

Başeren, S H ‘Doğu Akdeniz Deniz Yetki Alanları Uyuşmazlığı' (2010) 8(14) Stratejik Araştırmalar Dergisi 129.

Başeren, S H 'Mısır-Yunanistan anlaşması ve Türkiye'nin Doğu Akdeniz'deki Uygulamaları' (AA, 2020) < https://www.aa.com.tr/tr/analiz/misir-yunanistan-anlasmasi-ve-turkiye-nin-doguakdeniz-deki-uygulamalari/1953584> Erişim tarihi 28 Kasım 2020.

Bayıllığlu U, 'Uluslararası Adalet Divanının Romanya ile Ukrayna Arasındaki Deniz Alanı Sınırlandırmasında Serpents Adasının Etkisine İlişkin Tespitleri' (2010) 7(1) Cankaya University Journal of Law 23.

BM Güvenlik Konseyi’nin 186 nolu kararı (4 Mart 1964) UN Doc S/RES/186.

BM Güvenlik Konseyi’nin 541 nolu kararı (18 Kasım 1983) UN Doc S/RES/541. 
Butler, D and Gumrukcu, T 'Turkey Signs Maritime Boundaries Deal with Libya amid Exploration Row' (Reuters, 28.11.2019) < https://www.reuters.com/article/us-turkey-libya/turkey-signsmaritime-boundaries-deal-with-libya-amid-exploration-row-idUSKBN1Y213I> Erişim tarihi 1 Şubat 2021.

Cafiero, G 'Why is Greece mending relations with Assad?' ( Middle East Eye, 2020) < https://www. middleeasteye.net/opinion/greece-syria-assad-mending-relations-turkey-threat $>$ Erişim tarihi 26 Kasim 2020.

Can, F 'Doğu Akdeniz'de Ne Kadar Doğal Gaz Var?' (Euronews, 2020) <https://tr.euronews. com/2019/12/31/dogu-akdeniz-ne-kadar-dogal-gaz-rezervi-var-en-buyuk-payi-hangi-ulkeleralacak> Erişim tarihi 26 Kasım 2020.

'Certificate of Registration' (UN, 11 Aralı 2019) <https://treaties.un.org/doc/ Treaties/2019/12/20191211\%2002-58\%20PM/Other\%20Documents/COR-Reg-56119Sr-69975.pdf> Erişim tarihi 28 Kasım 2020.

Corbet, S “Southern EU Leaders Urge Turkey to End 'Unilateral' Actions," (The Washington Post, 10.09.2020) <https://www.washingtonpost.com/world/national-security/macron-urges-tougheu-stance-against-turkish-provocations/2020/09/10/5a53f3dc-f356-11 ea-8025-5d3489768ac8 story.html> Erişim Tarihi 1 Şubat 2021.

Doğru S, 'Doğu Akdeniz'de Hidrokarbon Kaynakları ve Uluslararası Hukuka Göre Bölgedeki Kıta Sahanlığı ve Münhasır Ekonomik Bölge Alanlarının Sınırlandırılması' (2015) 119 Türkiye Barolar Birliği Dergisi 503

Duran, H "BM ve AB Çerçevesinde Kıbrıs Sorununa Güncel Bir Bakış" (2008) 21 Dumlupınar Üniversitesi Sosyal Bilimler Dergisi 119-139.

'Eastmed' (2020) <http://www.igi-poseidon.com/en/eastmed> Erişim Tarihi 28 Kasım 2020.

Elhennawy, N "Egypt, Greece Sign Maritime Deal to Counter Libya-Turkey One" The Washington Post, 2020) <https://www.washingtonpost.com/world/middle_east/egypt-greece-sign-maritimedeal-to-counter-libya-turkey-one/2020/08/06/896646a8-d802-11ea-a788-2ce86ce81129_story. html> Erişim tarihi 1 Şubat 2021.

Ergüven N S, 'Karadeniz'de Deniz Alanı Sınırlandırması Davası (Romanya/Ukrayna) ve Uluslararası Hukuk Açısından Etkileri’ (2014) 63(2) Ankara Üniversitesi Hukuk Fakültesi Dergisi, 309-328.

Ermağan, İ ve Karc1, A “Avrupa Birliği’nin Yumuşak Güç Uygulamaları”, in Dr. Ayhan Nuri Yılmaz ve Dr. Gökmen Kılıçoğlu (eds), Yumuşak Güç ve Kamu Diplomasisi Üzerine Akademik Analizler, (Nobel Yayınc1lık, 2018) 411-437.

Eritre/Yemen Davas1, Eritrea-Yemen Arbitration (Second Stage: Maritime Delimitation) (2001) 40(4) International Legal Materials 983.

"European Council Conclusions" (12-13 December 2019) https://www.consilium.europa.eu/en/ meetings/european-council/2019/12/12-13/ Erişim tarihi 1 Şubat 2021.

European Council, "Statement of the Members of the European Council," SN 18/21, 25 March 2021.

"European Foreign Affairs Council Conclusions" (13 Temmuz 2020) <https://www.consilium. europa.eu/en/meetings/fac/2020/07/13/ > Erişim tarihi1 Şubat 2021.

European External Action Service, "Statement by the High Representative/Vice-President Josep Borrell on Renewed Drilling Activities by Turkey in the Eastern Mediterranean", (16 Ağustos 2020) <https://eeas.europa.eu/headquarters/headquarters-homepage/84111/statement-highrepresentativevice-president-josep-borrell-renewed-drilling-activities-turkey_en $>$ Erişim Tarihi 
1 Şubat 2021.

European External Action Service, "Video Conference of Foreign Affairs Ministers: Main Outcomes", (14 Ağustos 2020) <https://eeas.europa.eu/headquarters/headquartershomepage/84103/video-conference-foreign-affairs-ministers-main-outcomes_en $>$ Erişim tarihi 1 Şubat 2021.

Evans M D, International Law (Oxford University Press 2003)

Fransa/Kanada Davas1, Court of Arbitration for the Delimitation of Maritime Areas between Canada and France: Decision in Case concerning Delimitation of Maritime Areas(St. Pierre and Miquelon), 1992 International Legal Materials 31(5) 1145.

'Granted Licences' (2020) <http://www.mcit.gov.cy/mcit/hydrocarbon.nsf/page16_en/page16_ en?OpenDocument> Erişim tarihi 27 Kasım 2020.

“Greece, Israel, Cyprus Sign Deal for EastMed Gas Pipeline," (Kathimerini, 02.01.2020) < https:// www.ekathimerini.com/248073/article/ekathimerini/news/greece-israel-cyprus-sign-deal-foreastmed-gas-pipeline> Erişim tarihi 1 Şubat 2021.

"Greece to Request EU Foreign Affairs Council Emergency Meeting amid Tensions over Turkish Drilling”, (Euronews, 2020), <https://www.euronews.com/2020/08/10/tensions-grow-betweengreece-and-turkey-over-exploratory-drilling $>$ Erişim Tarihi 1 Şubat 2021.

Gur, V T “Turkey's Isolation From The Regionalization Process in The Eastern Mediterranean: A Case Study of The Eastern Mediterranean Gas Forum (EMGF)" (Master thesis, Ihsan Dogramaci Bilkent University 2020).

Guyana/Surinam Davas1, Award in the arbitration regarding the delimitation of the maritime boundary between Guyana and Suriname, Award of 17 September 2007 United Nations Reports of International Arbitral Awards Vol XXX para. 340-341; Bangladeş/Hindistan Davası, Award of 7 July $2014<$ https://pcacases.com/web/sendAttach/383> Erişim tarihi 24 Aralık 2020.

Hoffmann, C "Turkey-Greece conflict in eastern Mediterranean is less about gas than vaccum left by Trump," (The Conversation, 18.08.2020) < https://theconversation.com/turkey-greececonflict-in-eastern-mediterranean-is-less-about-gas-than-vaccuum-left-by-trump-144691> Erişim Tarihi 1 Şubat 2021.

'Italy, Cyprus Say Turkey-Libya Maritime Deal 'Unacceptable,' (ABC News, 29.01.2020), $<$ https://abcnews.go.com/International/wireStory/italy-cyprus-turkey-libya-maritime-dealunacceptable-68618477> Erişim tarihi 1 Şubat 2021.

İngiltere/Fransa Kita Sahanlığ Davas1, Delimitation of the Continental Shelf between the United Kingdom of Great Britain and Northern Ireland, and the French Republic (UK, France), International Law Reports, Vol. 54, 6.

'Joint Declaration Adopted by the Ministers of Foreign Affairs of Cyprus, Egypt, France, Greece and the United Arab Emirates', (11 Mayis 2020) <https:/www.mfa.gr/en/current-affairs/ statements-speeches/joint-declaration-adopted-by-the-ministers-of-foreign-affairs-of-cyprusegypt-france-greece-and-the-united-arab-emirates-11052020.html> Erişim tarihi 1 Şubat 2021.

Jan Mayen Davas1, Maritime Delimitation in the Area between Greenland and Jan Mayen, Judgment, I.C.J. Reports 1993, 38.

Katar/Bahreyn Davas1, Maritime Delimitation and Territorial Questions between Qatar and Bahrain, Merits, Judgment, I. C. J. Reports 2001, 40.

Kamerun/Nijerya Davas1, Land and Maritime Boundary between Cameroon and Nigeria (Cameroon v. Nigeria: Equatorial Guinea intervening), Judgment, I. C. J. Reports 2002, 303. 
Karbuz, S "Geostrategic Importance of East Mediterranean Gas Resources," (2018) Energy Economy, Finance and Geostrategy 237-255.

Karbuz, S ‘Doğu Akdeniz'de ne Kadar Doğal Gaz Var?' (2019) 12 Bilkent Enerji Notlart, <https:// drive.google.com/open?id=1DLMx9kmHcB2P2cTz73jp7yEmooehSDj9 > Erişim tarihi 22 Kasim 2020.

Kaya, İ S 'Uluslararası Deniz Hukuku Çerçevesinde Doğu Akdeniz’deki Petrol Ve Doğalgaz Kaynakları ile Türkiye'nin Hukuki Konumu' (PhD, Kırıkkale Üniversitesi 2014)

'Kıbrıs'<http://www.mfa.gov.tr/kibris.tr.mfa> Erişim tarihi 23 Kasım 2020

,KKTC‘ (TPAO) < https://www.tpao.gov.tr/kktc> Erişim tarihi 27 Kasım 2020.

Koutantou, A 'Greece, Israel, Cyprus sign EastMed gas pipeline deal' (Reuters, 2020) https://www. reuters.com/article/us-greece-cyprus-israel-pipeline-idUSKBN1Z10R5 Erişim tarihi 28 Kasım 2020.

Kuzey Denizi Kıta Sahanlığı Davası, Judgment, I.C.J. Reports 1969, 3.

Letter dated 11 July 2019 from the Chargé d'affaires a.i. of the Permanent Mission of Cyprus to the United Nations addressed to the Secretary-General Doc. A/73/944 (United Nations 2019) < https://undocs.org/en/A/73/944> Erişim tarihi 28 Kasım 2020.

Letter dated 13 November 2019 from the Permanent Representative of Cyprus to the United Nations addressed to the Secretary-General Doc. A/74/549 (United Nations 2019) < https:// undocs.org/A/74/549> Erişim tarihi 28 Kasım 2020.

Letter dated 18 March 2020 from the Permanent Representative of Turkey to the United Nations addressed to the Secretary-General, United Nations General Assembly Doc. A/74/757 (United Nations 2020) <https://undocs.org/en/A/74/757> Erişim Tarihi 24 Aralık 2020.

Libya-Malta Kıta Sahanlığı Davası, Continental Shelf (Libyan Arab Jamahiriya/Malta), Judgment, I. C.J. Reports 1985, 13.

Maine Körfezi Davas1, Delimitation of the Maritime Boundary in the Gulf of Maine Area, Judgment, I. C.J. Reports 1984, 246.

'No Big Impact on Turkey-EU Relations From Gas Drilling Spat - Pundits,' (Sputnik International, 16.07.2019) <https://sptnkne.ws/7ppp> Erişim tarihi : 1 Şubat 2021.

Özarslan, B B 'Uluslararası Hukuk ve Avrupa Birliği Hukuku Açısından Kıbrıs Sorunu' (PhD, Dokuz Eylül Üniversitesi 2006)

Peru/Şili Davası, Maritime Dispute (Peru v. Chile), Judgment, I.C.J. Reports 2014, 3.

Romanya/Ukrayna Davas1, Maritime Delimitation in the Black Sea (Romania v. Ukraine), Judgment, I.C.J. Reports 2009, 61.

Shaw M N, International Law (Cambridge University Press 2017)

Stanic, A ve Karbuz, S 'The Challenges Facing Eastern Mediterranean Gas and How International Law Can Help Overcome Them' (2020) Journal of Energy \& Natural Resources Law $<$ https:// doi.org/10.1080/02646811.2020.1816739> Erişim tarihi 22 November 2020.

Taş̧̧ığlu, Ö L “GKRY’nin Münhasır Ekonomik Bölge Anlaşmaları ve Petrol ve Doğal Gaz Arama Çalışmaları” (2018) 4 Social Sciences Studies Journal 5697-5709.

'TC Dışişleri Bakanlığı'nın GKRY'nin AB Üyeliği ile ilgili Açıklaması' (2004) <http://www.mfa. gov.tr/tc-disisleri-bakanligi_nin-gkry_nin-ab-uyeligi-ile-ilgili-aciklamasi-_1-mayis-2004_. tr.mfa> Erişim tarihi 23 Kasım 2020.

Tanaka Y, The International Law of the Sea (Cambridge University Press, 2019) 
Temizer, M 'Türkiye'nin Denizlerdeki Enerji Filosu' (AA, 2020) <https://www.aa.com.tr/tr/ ekonomi/turkiyenin-denizlerdeki-enerji-filosu/1949802> Erişim tarihi 26 Kasım 2020.

Tunus-Libya Kıta Sahanlığı Davası, Continental Shelf(Tunisia/Libyan Arab Jamahiriya), Judgment, I.C.J. Reports 1982, 18.

'Turkish and Greek Warships Collide in Eastern Mediterranean,' (Independent, 14.08.2020) <https:// www.independent.co.uk/news/world/europe/turkey-greece-war-mediterranean-erdogan-shipscollide-a9670416.html > Erişim tarihi 1 Şubat 2021.

'Türkiye Cumhuriyeti ile Kuzey Kıbrıs Türk Cumhuriyeti Arasında Akdeniz'de Kıta Sahanlığı Sınırlandırılması Hakkında Anlaşmanın Onaylanmasının Uygun Bulunduğuna Dair Kanun' (12.07.2012) <https://www.resmigazete.gov.tr/eskiler/2012/07/20120712-3.htm> Erişim tarihi 26 Kasim 2020.

'Türkiye Cumhuriyeti Hükümeti ile Libya Devleti Ulusal Mutabakat Hükümeti Arasında Akdeniz'de Deniz Yetki Alanlarının Sınırlandırılmasına ilişkin Mutabakat Muhtırası' (Resmi Gazete, 7 Aralık 2019) https://www.resmigazete.gov.tr/eskiler/2019/12/20191207-3.pdf Erişim tarihi 28 Kasım 2020.

'Türkiye - KKTC Kıta Sahanlığı Sınırlandırma Anlaşması İmzalanmasına İlişkin Dışişleri Bakanlığı Basın Açıklaması' (2011) <http://www.mfa.gov.tr/no_-216_-21-eylul-2011-turkiye_-kktc-kita-sahanligi-sinirlandirma-anlasmasi-imzalanmasina-iliskin-disisleri-bakanligi-basinac_.tr.mfa $>$ Erişim tarihi 26 Kasım 2020.

Tzimitras, H ve Hatay, M 'The Need For Realism: Solving The Cyprus Problem Through Linkage Politics' (2016) Turkey Project Policy Paper $9<\mathrm{https} / /$ www.brookings.edu/wp-content/ uploads/2016/10/turkey_20161005_cyprus_problem.pdf> Erişim tarihi 23 Kasım 2020.

Vatansever, M 'Kıbrıs Sorununun Tarihi Gelişimi' (2010) 12 Dokuz Eylül Üniversitesi Hukuk Fakültesi Dergisi 1487-1530.

'What the world said after referanda?' (2004) < http://www.mfa.gov.tr/what-the-world-said-afterthe-referanda.en.mfa $>$ Erişim tarihi 31 Ocak 2021.

Yaycı C, 'Doğu Akdeniz'de Deniz Yetki Alanlarının Paylaşılması Sorunu ve Türkiye' (2012) 4(6) Bilge Strateji 1-70.

Yüksel, C ve Baran, D 'Uluslararası Hukukta Doğu Akdeniz Krizi ve Türkiye ile Libya Arasındaki Deniz Yetki Alanlarını Sınırlandırma Mutabakatının Değerlendirilmesi’ (2020) 40(1) PPIL https://doi.org/10.26650/ppil.2020.40.1.0019 Erişim tarihi 28 Kasım 2020. 
